\title{
Conservation of semi-natural grasslands: Effects of different management methods on biodiversity
}

\author{
Malin Tälle
}

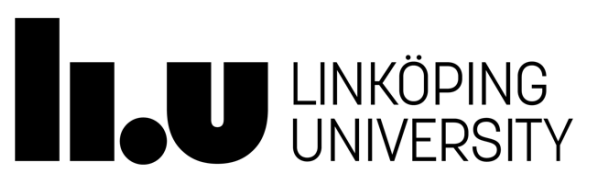

Department of Physics, Chemistry and Biology

Division of Biology

Linköping University, Sweden

Linköping 2018 
Tälle, M. 2018. Conservation of semi-natural grasslands: Effects of different management methods on biodiversity

(c) Malin Tälle, 2018

Cover: Semi-natural grassland in southern Sweden

Photo: Karl-Olof Bergman

Published articles have been reprinted with the permission of the copyright holders.

Printed in Sweden by LiU-Tryck, Linköping, Sweden, 2018

ISBN 978-91-7685-379-5

ISSN 0345-7524

Also available at LiU Electronic Press 
"For in the end, we will conserve only what we love, we will love only what we understand, and we will understand only what we are taught"

Baba Dioum 



\section{ABSTRACT}

Species-rich semi-natural grassland are valuable habitats in the agricultural landscape as they may contain a high diversity of both plant and animal species, as well as provide essential ecosystem services like pollination. To keep these habitats open and to maintain the biodiversity in them, management like grazing or mowing is necessary. Due to changed agricultural practices many semi-natural grasslands have been lost, e.g. due to secondary succession after abandonment or use of more intense management practices. As limited resources are available for the management and restoration of semi-natural grasslands, research is needed to find the best available management method that maintains biodiversity at a low cost. Therefore, the overall aim of this thesis was to use existing data to compare effects of different management methods and explore their effect on the biodiversity of semi-natural grasslands. More specifically, effects of grazing vs. mowing, different mowing frequencies and different mowing techniques were investigated using data from Swedish, European and global studies, with the aim of using the results to formulate management recommendations.

Paper I investigated the effect of mowing using a sickle bar mower or a grass trimmer at a $5-\mathrm{cm}$ or $\mathrm{O}-\mathrm{cm}$ cutting height on plant indicator species of good management for species richness, poor management and excess nitrogen. Analyses of data from a Swedish 11-year field experiment revealed that over time, there was no difference in the odds of finding indicators of any type for any of the mowing techniques. This suggest that there is a similar effect of mowing using a sickle bar mower and a grass trimmer on the floristic composition of semi-natural grasslands.

Paper II and III investigated effects of different management methods using a Swedish long-term, multi-site field experiment. Paper II compared effects of grazing vs. mowing and paper III compared effects of annual mowing and mowing every third year. Both papers used meta-analyses to compare effect on plant indicator species of good management for species richness and poor management. Additionally, paper II examined effects of indicators of excess nitrogen, while paper III also examined effects on plant species richness and diversity and species-wise responses. For paper II, analyses revealed an increase in the odds of finding indicators of good management for species richness in mowed plots and increased odds of finding indicators of excess nitrogen in grazed plots. For paper III, meta-analyses revealed a small drop in plant species richness and diversity, and an increase in woody and tall-grown species, when mowing every third year. However, there were no difference in the odds of finding indicators of good management for species richness or poor management between mowing frequencies. These results suggest that mowing is a better long-term management method compared to grazing in semi- 
natural grasslands in southern Sweden, while annual mowing have a slightly more positive effect compared to mowing every third year.

Paper IV and V investigated management effects on a larger scale, by systematically reviewing studies comparing effects of grazing vs. mowing or different mowing frequencies on grassland flora and fauna, and analysing the data using meta-analysis. The included mowing frequencies were annual mowing vs. mowing every fifth, third or second year, or mowing two, three or four times a year. Paper IV analysed data from 35 studies from across the globe, and revealed a slightly more positive effect of grazing on the biodiversity of seminatural grasslands. However, results differed for different grassland characteristics like e.g. geography, grassland type and previous management. Paper V analysed data from 29 European studies, and revealed a more positive effect of mowing more frequently than once per year. However, the differences were small and varied for different grassland characteristics. For example, a higher mowing frequency was better in more productive grasslands. These results suggest that grazing is slightly better than mowing and that mowing less frequently, e.g. every other year, can be a viable management method in less productive grasslands, as a way of using limited funds more efficiently.

The results from the papers included in this thesis suggest that different management methods have different effects on the biodiversity of semi-natural grasslands. However, in many cases these differences are relatively small. Thus, to a certain extent one of the most important factors for semi-natural grassland biodiversity seems to be the fact that management occurs at all, while the actual management methods is of less importance. Hence, choosing the most suitable management method for a certain situation should be based on conservation aims, grassland conditions, the previous management practice used, the cost of management, the availability of different management methods and previous research. 


\section{POPULÄRVETENSKAPLIG SAMMANFATTNING}

Näringsfattiga ängs- och hagmarker är en viktig del av jordbrukslandskapet, då de ofta innehåller en hög artrikedom av både växt- och djurarter, samtidigt som de bidrar till upprätthållandet av viktiga ekosystemtjänster som exempelvis pollinering. För att bevara diversiteten i dessa habitat är det viktigt att de sköts på rätt sätt, via exempelvis bete eller slåtter, eftersom dessa skötselmetoder motverkar igenväxning av gräsmarker, samtidigt som de bibehåller de näringsfattiga förhållandena genom avlägsnandet av biomassa. På grund av intensifierade jordbruksmetoder har många artrika ängs- och hagmarker gått förlorade. Detta beror bland annat på att skötsel upphört på grund av för låg avkastning, eller en ökad användning av gödsling som förändrat förhållandena i gräsmarkerna. Med anledning av detta har många av de arter som är bundna till denna habitattyp blivit mer ovanliga och hotade. Begränsade resurser är tillgängliga för skötsel och restaurering av ängs- och hagmarker och därför behövs forskning som undersöker effekten av olika skötselmetoder, för att hitta de som har mest positiv effekt till en så låg kostnad som möjligt. Det övergripande målet med denna avhandling var därför att undersöka effekten av olika skötselmetoder på diversiteten i ängs- och hagmarker, för att ta fram passande skötselrekommendationer.

Slåtter med verktyg som gräsröjare, som sliter sönder vegetationen, har länge ansetts ha en negativ effekt i jämförelse med skärande verktyg som exempelvis lie eller slåtterbalk, men få studier har undersökt detta. I artikel I undersöktes därför effekten av olika slåttermetoder på växter, i en ängsmark i södra Sverige. De undersökta metoderna var slåtter med slåtterbalk och slåtter med gräsröjare på två olika klipphöjder (o eller $5 \mathrm{~cm}$ ). Effekterna undersöktes på indikatorarter för god hävd, brist på hävd och överskott av kväve. Resultaten visade att oddsen för att hitta de olika indikatorarterna inte skiljde sig mellan slåttermetoderna, vilket tyder på att de har en liknande effekt på vegetationen i ängsmarker.

Artikel II jämförde effekten av bete och slåtter och artikel III effekten av slåtter en gång per år och slåtter vart tredje år. Bägge artiklarna använde sig av data från ett långtidsexperiment som utfördes i elva olika gräsmarker i södra Sverige, och jämförde skötseleffekter på växtindikatorarter för god hävd och brist på hävd. Artikel II undersökte även effekten på indikatorarter för överskott av kväve medan artikel III även tittade på effekter på artrikedom och diversitet, samt effekter på individuella arter. I artikel II visade analyserna att oddsen att hitta indikatorer för god hävd ökade med slåtter medan oddsen att hitta indikatorer för överskott av kväve ökade med bete. Analyserna i artikel III visade på en liten minskning av artrikedomen och diversiteten samt en ökning av vedarter och högväxta arter vid slåtter vart tredje år. Det fanns dock ingen skillnad i oddsen att hitta indikatorarter för god hävd eller brist på hävd mellan de två slåtterfrekvenserna. Dessa resultat tyder på att slåtter är en bättre 
skötselmetod. jämfört med bete, medan slåtter en gång per år har en något mer positiv effekt jämfört med slåtter vart tredje år.

Artikel IV och V undersökte effekten av skötselmetoder på en större skala, genom att systematiskt gå igenom, granska och analysera data från studier som undersökt effekterna av bete och slåtter och olika slåtterfrekvenser, på floran och faunan i ängs- och hagmarker. Artikel IV analyserade data från 35 studier från hela världen som jämfört bete och slåtter, och fann en något mer positiv effekt av bete jämfört med slåtter på diversiteten av växt- och djurarter. Dock skiljde sig effekterna beroende på förhållandena i de undersökta gräsmarkerna, exempelvis beroende på geografi, gräsmarkstyp och tidigare skötsel. Artikel V analyserade data från 29 europeiska studier som jämfört slåtter en gång per år med slåtter vart femte, tredje eller vartannat år, eller slåtter två, tre eller fyra gånger per år. Analyserna visade på en något mer positiv effekt av slåtter oftare än en gång per år, men skillnaderna mellan slåtterfrekvenserna var små och de skiljde sig beroende på förhållandena i gräsmarkerna. Exempelvis så var en högre slåtterfrekvens bättre i mer produktiva gräsmarker. Resultaten från dessa två artiklar tyder på att bete är något bättre än slåtter, och att i mindre produktiva gräsmarker kan slåtter mer sällan än en gång per år, exempelvis vartannat år, vara ett sätt att använda de begränsade resurserna tillgängliga för skötsel på ett mer effektivt sätt.

Resultaten från artiklarna i denna avhandling visar att olika skötselmetoder har olika effekt på diversiteten i ängs- och hagmarker. Dock var dessa skillnader relativt små, vilket tyder på att i viss utsträckning är den viktigaste faktorn att skötsel faktiskt sker, medan själva skötselmetoden är av mindre betydelse. Därför är det viktigt att basera valet av skötselmetod i ett specifikt fall på bevarandemål, abiotiska förhållanden, tidigare skötselmetoder, kostnaden och tillgängligheten för olika skötselmetoder samt tidigare forskning. 


\section{LIST OF PUBLICATIONS}

I Tälle, M., Bergman, K.-O., Paltto, H., Pihlgren, A., Svensson, R., Westerberg, L., Wissman, J., Milberg, P. 2014. Mowing for biodiversity: Grass trimmer and knife mower perform equally well. Biodiversity and Conservation, 23, 3073-3089.

II Tälle, M., Fogelfors, H., Westerberg, H., Milberg, P. 2015. The conservation benefit of mowing vs grazing for management of species-rich grasslands: a multi-site, multi-year field experiment. Nordic Journal of Botany, 33, 761768.

III Milberg, M., Tälle, M., Fogelfors, H., Westerberg, L. 2017. The biodiversity cost of reducing management intensity in species-rich grasslands: mowing annually vs. every third year. Basic and Applied Ecology, 22, 61-74.

IV Tälle, M., Deák, B., Poschlod, P., Valkó, O., Westerberg, L., Milberg, P. 2016. Grazing vs. mowing: a meta-analysis of biodiversity benefits for grassland management. Agriculture, Ecosystems and Environment, 222, 200-212.

V Tälle, M., Deák, B., Poschlod, P., Valkó, O., Westerberg, L., Milberg, P. Similar effects of different mowing frequencies on the conservation value of semi-natural grasslands in Europe. Submitted.

Contributions to the papers

Malin Tälle made major contributions in shaping the ideas, formulating the questions, choosing methodologies and interpreting the results of paper I-V. For paper I MT contributed to the data collection and for paper I-II MT was responsible for the analyses and drafting the manuscripts. For paper III, MT contributed to analyses and writing the manuscript. For paper IV-V MT was responsible for systematically reviewing literature, compiling of data, analyses and drafting the manuscripts.

All papers have been reprinted with permission from the respective publisher. 


\section{ACKNOWLEDGEMENTS}

During my PhD I have ended up working with many of the people who were previously my teachers. First and foremost, I want to thank them for teaching me to understand and love biology!

My warmest gratitude to my three supervisors for providing support and encouragement throughout my years as a PhD student, and for giving me the opportunity to grow as a researcher and a human being. Thank you Lars for being the perfect combination of challenging and encouraging, for pushing me to go further in my thinking and research and for being such a structured and dependable supervisor. Per, thank you for believing in me and giving me the initial opportunity to work with our projects and make my own way as a researcher. Your enthusiasm and encouragement have been so valuable, especially when I have been too good at being pessimistic. Uno, thanks for believing in me and for being so enthusiastic and supportive of my research, even when it is a bit outside your main area, and for giving me the opportunity to be so independent.

I want to thank all of my colleagues, both at the Theoretical Biology and the Biology departments, for providing such a great research environment. A special thanks to the people at Theoretical Biology (past and present) for providing excellent company and such varied conversations over coffee and lunch. How will you ever manage to take your breaks on time when I leave? I also want to thank the people, both staff and students, who have made teaching such an enjoyable experience. Also, thanks to Kalle for snapping the amazing picture on the cover of the thesis. A big thank you to the collaborators for the projects I have been involved in. Without them much of my research would have been impossible. I am also indebted to those responsible for performing the studies from which I have used data in my own projects.

A big thank you to my friends, who always provide a great way of taking my mind of work, be it by playing board games or just hanging out. Lots of love to my amazing mother Sussie and brothers Emil and Rasmus, who are as wonderfully random and weird and awesome as me and who always supports me no matter what.

To Petter - thank you for being nothing but supportive and awesome and for always listening to me vent my frustrations and sharing in my joy. Without your company I would probably have gone crazy with stress during the last months. Thank you for letting me be me, and for you being you.

And finally, thanks to myself, who actually managed to do this. When I started studying biology I had this vague idea of doing a PhD in the future. And now, here I am, actually having done it. Who knows what will happen in the future, but I do know that I am going to science the shit out of this planet! 


\section{CONTENTS}

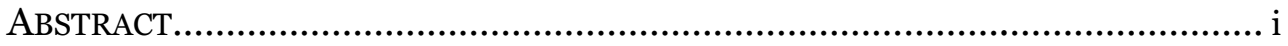

POPULÄRVETENSKAPLIG SAMMANFATTNING........................................... iii

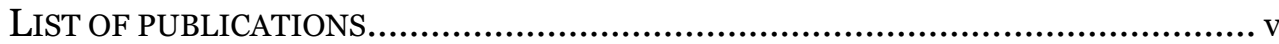

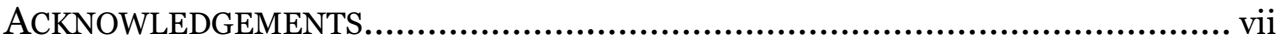

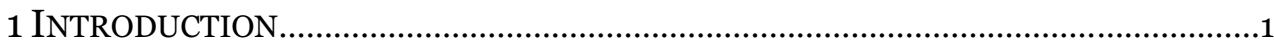

1.1 Semi-natural grasslands and their importance...................................................

1.2 The importance of management of semi-natural grasslands.................................

1.3 Grazing and mowing and their effect on semi-natural grasslands........................5

1.4 Studies investigating effects on grazing and mowing............................................

1.5 Meta-analysis...........................................................................................

1.5.1 Prospects of using meta-analysis when evaluating management effects in semi-natural grasslands ...........................................................10

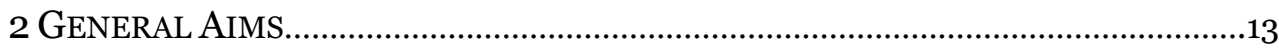

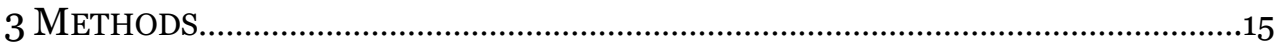

3.1 Comparing management effects in Swedish semi-natural grasslands................15

3.1.1 Study sites and experimental design.................................................15

3.1.2 Analysis methods...............................................................................17

3.2 Comparing management effects reported in the literature..................................17

3.2.1 Retrieving the data........................................................................17

3.2.2 Analysis methods........................................................................19

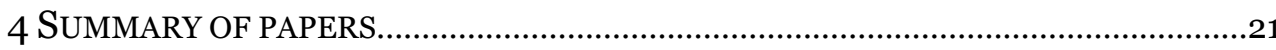

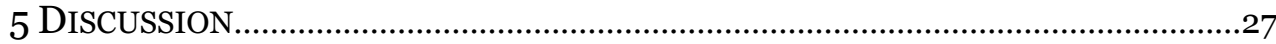

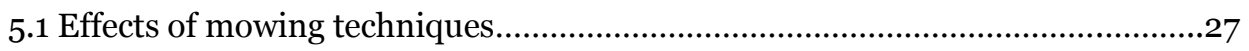

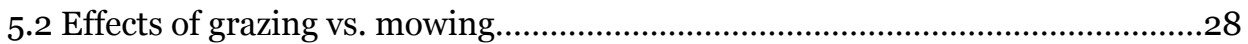

5.3 Effects of different mowing frequencies...........................................................32

5.4 The robustness of the conclusions.......................................................................

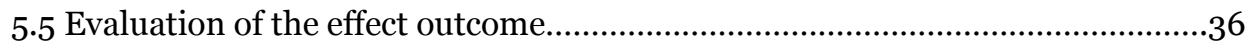

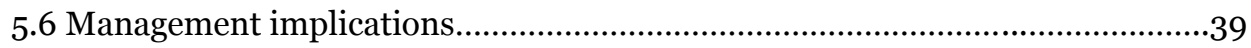

5.7 Further research topics..............................................................................

5.8 Conclusions.........................................................................................42

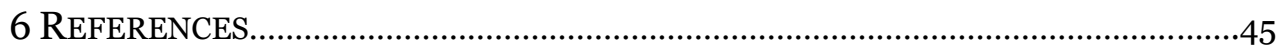

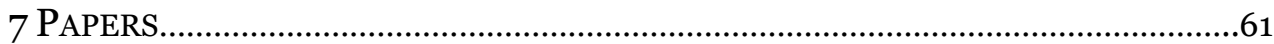




\section{INTRODUCTION}

Due to ongoing changes in agricultural practices and landscapes, the conservation of biodiversity associated with traditionally managed semi-natural grasslands have become increasingly more important. For the development of relevant management recommendations, there is a need for research investigating management effects on semi-natural grasslands. In this thesis, papers investigating effects of grazing, mowing and different mowing techniques and frequencies have been used to formulate management recommendations that facilitate the conservation of biodiversity in semi-natural grasslands.

\subsection{Semi-natural grasslands and their importance}

Semi-natural grasslands are defined as open habitats with a grass- and forbdominated vegetation, with a low proportion of woody species (Crofts \& Jefferson 1999). Grasslands in general have been formed in climates not suitable for woody vegetation (e.g. steppe or prairie), or are kept open by natural disturbances such as fire or the presence of wild megaherbivores. Semi-natural grasslands have been formed by human activities since the Neolithic Age (Bradshaw \& Mitchell 1999, Gibson 2009, Pärtel et al. 2005). Traditional agricultural practices used during several centuries have created and maintained these habitats (Hejcman et al. 2013), and they have traditionally not been subjected to use of inorganic fertilizers or pesticides.

There are several different types of semi-natural grasslands, which occurs in different climates, and on different soil types and moisture conditions. The three main types of semi-natural grasslands occurring in Europe are neutral or mesotrophic grasslands, which usually occurs on moderately moist mineral soils with neutral soil pH; calcareous grasslands, which typically exists on dry soil on pervious calcareous bedrock; and wet grasslands, which exists on soils with a high ground-water table for most of the year (Crofts \& Jefferson 1999). Different types of semi-natural grasslands contain distinct vegetation and are characterized by different plant species. Many of these species are confined to this habitat type, as they have adapted to and depend on conditions like those present in semi-natural grasslands (e.g. nutrient and light conditions).

Semi-natural grasslands can maintain a very high biodiversity (Pärtel et al. 2005, Wallis De Vries et al. 2002) and harbour a high number of both plant (e.g. Chytrý et al. 2015, Verrier \& Kirkpatrick 2005, Zhou et al. 2002) and animal species (e.g. D’Aniello et al. 2011, Pärt \& Söderström 1999). Some meadows in the central part of Europe belong to the most species-rich habitats within the landscape (Wilson et al. 2012), and in Northern Europe up to 6o plant species per square meter have been reported (Kull \& Zobel 1991). This biodiversity is one important factor for the stability of food webs in grasslands and supply of 
the essential ecosystem services provided by semi-natural grasslands (Balvanera et al. 2006, Haddad et al. 2011, Hooper et al. 2005). For example, flower-rich, natural areas such as semi-natural grasslands are important habitats for wild pollinators of crops (Öckinger \& Smith 2007), with decreasing pollinator diversity, visitation rate and fruit set with increasing distance to natural habitats (Garibaldi et al. 2011) or loss of natural areas. This habitat type also provides water regulation (e.g. flood and drought prevention), as grasslands are $20 \%$ more effective than cropland in reducing water runoff (Hönigová et al. 2012). The vegetation in semi-natural grasslands also protects from soil erosion as e.g. plant roots helps prevent the loss of top soil (Bazzoffi 2009). Furthermore, seminatural grasslands and the biodiversity in them provide recreation and contribute to human aesthetics (Figure 1).

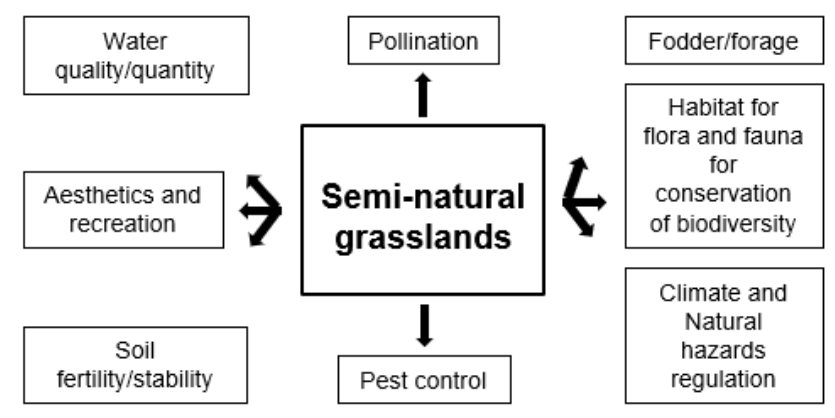

Figure 1 | Ecosystem services potentially delivered by semi-natural grasslands. Adapted from Lamarque et al. 2011.

\subsection{The importance of management of semi-natural grasslands}

Management, in the form of e.g. clearing of trees and bushes and grazing or mowing (i.e. removal of biomass by livestock or cutting of vegetation with subsequent removal of the cut material), is required to support species-rich semi-natural grasslands. This is to prevent afforestation and to keep these habitats open, as it prevents encroachment of woody species and subsequent loss of species (e.g. Hansson \& Fogelfors 2000, Köhler et al. 2005, Schreiber et al. 2009), and to promote biodiversity through increased light availability and the depletion of nutrients (Al-Mufti et al. 1977, Einarsson \& Milberg 1999, Oelmann et al. 2009). This in turn may limit the ability of competitive species to achieve dominance (Knop et al. 2006) and prevent the loss of plant species that are adapted to e.g. high light availability and low nutrient levels. Based on previous research and ecological theories on the importance of disturbance levels, spatial and temporal heterogeneity and meta-communities for bio- 
diversity (Box 1), there is a clear association between high species richness, occurrence of rare species and the management of semi-natural grasslands (Klimek et al. 2007, Pykälä 2003).

\section{Box 1 | Ecological theories explaining high plant diversity}

Several ecological theories attempt to explain the high species diversity in seminatural grasslands and the link to management. Fundamental for these is niche theory, as defined by Grinell or Hutchinson (Leibold 1995), which state that for coexistence species must occupy different ecological niches or competitive exclusions between species will occur. A plant species' niche consists of its resource needs, habitat requirements and environmental tolerance, e.g. nutrient and water requirements, $\mathrm{pH}$ and temperature tolerance, and is also highly affected by the competition between species. In addition, favourable conditions for e.g. flowering, seed set, germination and seedling establishment (i.e. the regeneration niche) are important parts of a species' niche, to ensure species survival over time (Crawley 1997, Grubb 1977). In short, a habitat with many different potential niches can contain a higher species richness. In semi-natural grassland habitats, management (among others) affects which niches are available.

One theory which clearly links high species richness and management is the intermediate disturbance theory, which states that plant diversity is highest at intermediate levels of disturbance (e.g. grazing or annual mowing). At high disturbances the pool of adapted species is low, as few species can occupy a niche with high disturbance. This leads to the dominance of a few species and a lower diversity. At low disturbances competitive exclusions occur, as species more tolerant to low disturbance levels outcompete less tolerant species, also leading to lower diversity. At intermediate management levels the dominance of a few species is prevented, at the same time as the pool of potential colonist species is high, i.e. species that can occur in early or late successional stages can coexist (Crawley 1997).

Other theories state that the heterogeneity of grasslands is important for species diversity. High spatial heterogeneity is expected to increase species diversity, as it signifies that more and different niches are available, potentially leading to higher diversity. Management (grazing in particular) can be expected to increase the spatial heterogeneity, e.g. through the creation of small patches with varying species composition due to the trampling and nutrient input from dung (Adler, 2001, Crawley 1997). In addition, temporal heterogeneity is considered important for biodiversity. Within and between different seasons and years the conditions affecting species may differ, thereby affecting species communities and diversity. Temporal variability is mostly created by changing abiotic conditions, but can also be affected by management as e.g. vegetation height is affected by whether or not management has occurred, and flowering and seed set can be affected by the timing of management, in turn potentially affecting the diversity (Chesson 1986, Crawley 1997, Eriksson et al. 2015, Humbert et al. 2012). 
Box 1 | Continued.

Another important concept for biodiversity is that of meta-communities, and the trade-off between a species' competitive ability and dispersal ability. In a patchy landscape with several semi-natural grassland habitats situated relatively close together, it is possible for high biodiversity to be maintained, as species that are weak competitors in one grassland may be able to disperse to other grasslands with less competition, thereby promoting species coexistence (Holyoak et al. 2005). For this dispersal to be possible and successful, management of grassland patches is important to ensure the occurrence of suitable patches available for dispersal.

Debate on which of these theories (or combination of theories) are most likely to contribute most to our understanding of the high species diversity in semi-natural grasslands and why, is ongoing. There are empirical and theoretical studies both in favour and disfavor of all these theories, but discussion of this is beyond the scope of this thesis.

Since the second half of the $20^{\text {th }}$ century agricultural practices have been modernized and intensified, with increasing use of inorganic fertilizers and pesticides to increase yields. As a consequence, the use of traditional management methods like grazing and mowing has decreased, and considerable area of grasslands have been abandoned, been converted to arable land or highyielding grasslands or been converted to forests through tree planting or natural succession (Firbank 2005, Milberg 1995, Moog et al. 2002, Wahlman \& Milberg 2002). For example, approximately $90 \%$ of the area of semi-natural grassland in Sweden have been converted to other habitat types during the $21^{\text {st }}$ century (Eriksson et al. 2002, Ihse 1995), and trends are similar for the rest of Europe (Figure 2) (e.g. Biró et al. 2013, Dobrev et al. 2014, Ridding et al. 2015). This loss of semi-natural grassland area has a large negative effect on the species in them, negatively affecting biodiversity and increasing the risk of extinction (Bullock et al. 2011). Habitat loss also increase the isolation of habitats in the landscape, e.g. making species dispersal and subsequent successful colonization more difficult (Fahrig 2003). Because of this, the preservation of semi-natural grasslands is of high conservation priority. Because of the intensification of agricultural practices, subsidies from e.g. The European Union or the governments of individual countries have been used to protect semi-natural grasslands and maintain more traditional management practices, but the funds are limited (European Commission Directorate General for Agriculture and Rural Development, 2005). This makes it difficult to maintain expensive management methods like mowing (Schreiber et al. 2009, Török et al. 2011). In addition, the number of available livestock herds for grazing are decreasing (Kumm 2003), as an increasing number of potential grazers in Europe are kept in stables and fed silage (Poschlod 2015). Hence, it is very important to use a management method 
that maintain the high biodiversity of semi-natural grasslands, at the same time as it is cost-effective and practically achievable.
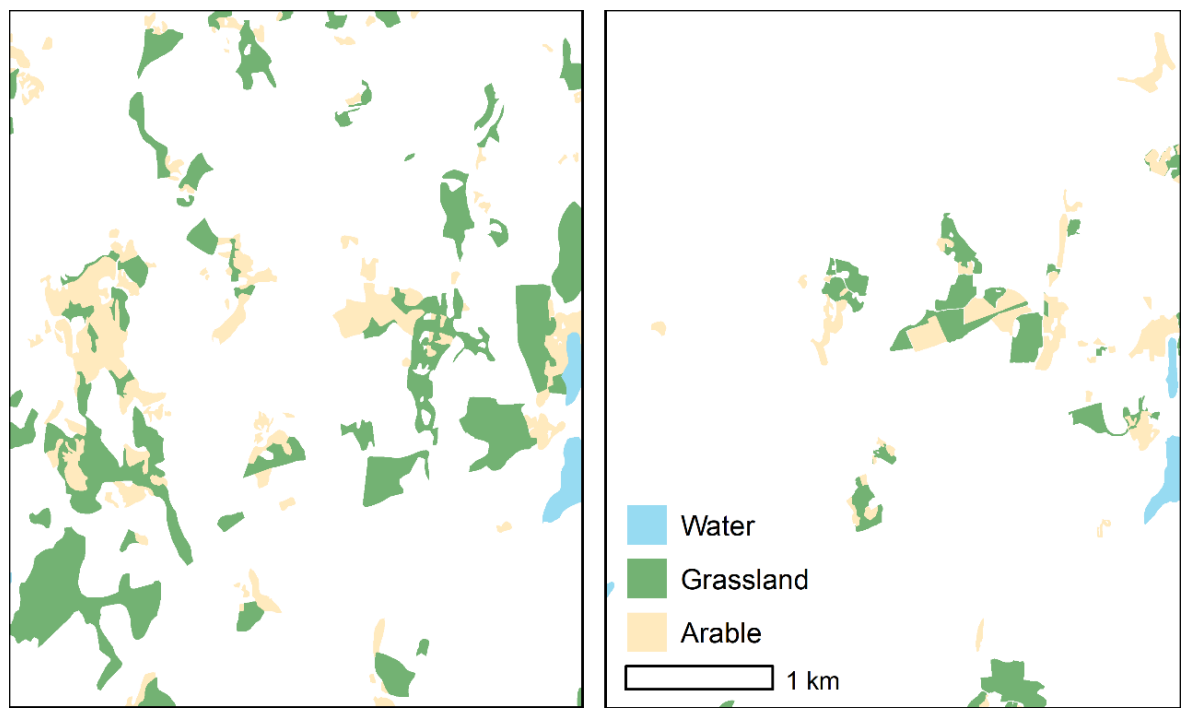

Figure 2 | The reduction and fragmentation of semi-natural grassland areas between 1877 (left) and 2016 (right), N-NW of Ulrika in Östergötland, southern Sweden. The left map is based on digitalisation of the Swedish District economic map (Häradsekonomiska kartan) available from Lantmäteriets historical map archive. The right map is based on the GDS Terrain Map Vector (Lantmäteriet CCo), with grassland positions based on information from the TUVA database and CadasterENV Sweden ver. 1.0.

\subsection{Grazing and mowing and their effects on semi-natural grasslands}

Grazing and mowing are the most common management methods used in seminatural grasslands. Other, less common, management options include burning of vegetation outside of the growing season and mulching, where the vegetation is cut in a similar way as for mowing but where the cut material is crushed and left in the grassland (Deák et al. 2014, Doležal et al. 2011). Grazing has been used since the Neolithic Period, when the domestication of livestock led to grazing of forests and clearings adjacent to settlements (and the creation of semi-natural grasslands). The application of mowing was introduced in the Roman Period and from the European Medieval Age onwards mowing for hay and grazing became vital parts of the mixed farming system that developed in Europe (Hejcman et al. 2013, Poschlod \& Wallis De Vries 2002). Hay-making was closely associated with the winter-stabling of livestock, summer grazing and availability of manure for fertilization of arable fields (Pedersen \& Widergren 
2011). Today, grazing may occur at different points during the growing season or throughout the entire season, usually depending on the grassland productivity, stocking rate and the amount of livestock available. In addition, in meadows mown during the summer, aftermath grazing is often applied (Gilhaus \& Hölzel 2016, Holechek 1988, Kumm 2003). Mowing usually takes place towards the end of summer (late July to August). However, mowing dates often differ between years (Eriksson et al. 2015) and in some cases mowing is performed more than once during the growing season (e.g. at the beginning and end of summer), or more seldom (e.g. every other year), also depending on grassland productivity (Crofts \& Jefferson 1999, Ekstam et al. 1988). Traditionally, mowing was performed using scythes, but from the second half of the $2 \mathrm{O}^{\text {th }}$ century onwards the use of mechanical tools like sickle bar mowers and tractor-pulled mowers became increasingly more common (Ekstam et al. 1988).

The plant communities in semi-natural grasslands differ depending on abiotic conditions and the regional species pool. However, the management method used also affects plant communities, as different methods have different effects on the vegetation (e.g. Catorci et al. 2014, Hansson \& Fogelfors 2000, Köhler et al. 2005, Schreiber et al. 2009), and contributes to the creation of different types of niches available for grassland species. For example, grazing is more selective compared to removing all vegetation at once by mowing, as plant species are grazed to a varying extent depending on e.g. the preference of the grazer and plant palatability (some plant species have evolved defence mechanisms such as prickliness or poisonousness to protect against grazing). Trampling and nutrient input from dung further differentiate grazing from mowing (Moretto \& Distel 1999, Rook et al. 2004). As a consequence, grazing usually creates a spatially heterogeneous vegetation consisting of small patches with different species composition (Adler et al. 2001), while the removal of all vegetation at once through mowing creates a more spatially homogenous plant community throughout a grassland (Lepš 2014). Mowing promotes plant species with early flowering and seed set to ensure seed dispersal before mowing occurs. For the same reason, mowing may also promote species that can regrow and set seed after management occurs (Brys et al. 2004, Chaudron et al. 2016). Effects of management also differ for other organism groups. Nectar-feeding insects are favoured by less intense management methods that ensure a high abundance of nectar-plants throughout the growing season, e.g. low intensity grazing (Milberg et al. 2016, Potts et al. 2003, Sjödin 2007). For animals such as birds, insects and small mammals, more intense management like mowing can have a more negative effect compared to grazing, as a consequence of the rapid loss of the vegetation that harbour these animals (Bellamy et al. 2000, Vickery et al. 2001, Wallis De Vries 2007). Furthermore, the plant and animal communities created and maintained by different management methods can, and have been, altered by changed management practices or the cessation of management. 


\subsection{Studies investigating effects of grazing and mowing}

As it is important to find the management method that best preserve the seminatural grassland biodiversity, several studies have focused on comparing effects of grazing and mowing, but results vary widely. Studies focusing on plant species have found results in favour of grazing (e.g. During \& Willems 1984, Gilhaus et al. 2017, Schläpfer et al. 1998), mowing (e.g. Catorci et al. 2014, Wahlman \& Milberg 2002) or both (e.g. Kahmen et al. 2002, Koncz et al. 2014). Studies evaluating effects on animal species such as insects have similarly found results in favour of both grazing (e.g. D'Aniello et al. 2011, Saarinen \& Jantunen 2005) and mowing (e.g. Radlmair \& Laußmann 1997). Hence, there is no clear answer to the question of whether grazing or mowing have the most positive effect on grassland biodiversity.

Results also vary for studies examining effects of grazing (on its own or in comparison with other management methods), and in addition to e.g. grassland type and previous management, it is important to consider the impact of the grazing intensity when evaluating grazing effects. Grazing intensity is a combination of the grassland productivity and removal rate (i.e. the length of the grazing period and the stocking rate), stocking rate (i.e. the amount of livestock per area unit) and animal type used (e.g. cattle, sheep or horses). Many of the studies investigating effects of grazing intensity suggest that a low to moderate stocking rate is best for grassland biodiversity (Deng et al. 2014, Török et al. 2016, van Noordwijk et al. 2012). However, other studies suggest that the livestock type can also be a very important factor for biodiversity (Tóth et al. 2016), due to the difference in e.g. body size, physiology and selectivity of different grazer types. For example, smaller herbivores select higher quality food compared to larger animals, and sheep are considered more selective grazers compared to cattle (Rook et al. 2004, Stewart \& Pullin 2008). Studies investigating effects of rotational grazing, i.e. grazing during two or more shorter periods throughout the growing season, suggest that rotational grazing has similar effects as grazing at a low intensity (Jacobo et al. 2006, Lagendijk et al. 2017).

The mowing regime used in semi-natural grasslands, i.e. the mowing frequency, mowing date and mowing technique used, differs somewhat for different regions and grassland types, and there are no clear, general conclusions from studies examining effects of mowing. Studies focusing on the effect of different mowing frequencies, e.g. annual mowing compared to mowing two times a year or every other year, on grassland biodiversity have found results in favour of mowing at least two times a year (e.g. Noordjik et al. 2009, Simões et al. 2013, Szépligeti et al. 2018) and mowing annually compared to more frequent cuts (e.g. Everwand et al. 2014, Jantunen et al. 2007, Kőrösi et al. 2014). In addition, some studies have found more positive effects of mowing less frequently than 
once per year (e.g. Gosteli 1996, Ryser et al. 1995). Some studies have examined effects of the timing of mowing on grassland biodiversity. Humbert et al. (2012) found a more positive effect of mowing in summer compared to spring- or autumn-mowing for plant species, while a later cut was better for invertebrate species. Other studies have also found a more positive effect of a later cut for invertebrate species (e.g. Bruppacher et al. 2016, Valtonen et al. 2006), while Beltman et al. (2003) revealed similar effect of different mowing dates on plant diversity. Very few studies have evaluated effects of mechanical mowing techniques compared to scythes or other mechanical techniques. A Swedish study by Svensson et al. (2009) did not reveal any differences in the effect on grassland flora when mowing using a sickle bar mower or a grass trimmer, in disagreement with the general management recommendations for meadows used in Sweden (Ekstam et al. 1988). Studies focused on the effects on invertebrates have found negative effects of mechanical mowing techniques (especially those using rotary mowers) (e.g. Humbert et al. 2009).

As evident from the studies comparing effects of different management methods, techniques and intensities, results differ between studies and it is therefore difficult to draw general conclusions on management effects on biodiversity. Many studies are short-term studies, making conclusions less certain. In addition, it is often challenging to directly compare results from different studies as they are performed in different types of grasslands with different plant and animal communities, reports effects on different types of organisms and use different methods and experimental designs. Hence, it is uncertain if the conclusions from a specific study are useful outside of a limited local area, and it becomes difficult to make general recommendations on which management methods ensure positive effects on semi-natural grassland biodiversity. Therefore, there is a need for studies that mitigate the differences between studies and arrive at more general results and conclusions.

\subsection{Meta-analysis}

Meta-analysis is a method designed to overcome differences between studies investigating a particular research question and to detect a general response. The concept of meta-analysis was initiated by Glass (1976), and can be defined as

A set of statistical methods for combining the magnitudes of outcomes (effect sizes) across different data sets addressing the same research question.

(Koricheva et al. 2013, p. 8)

In short, meta-analysis makes it possible to analyse results from several primary research studies at once, with the aim of finding an overall answer to a specific research question. This makes it possible to compare studies regardless of 
differences in e.g. experimental setup or examined populations, and to draw more general conclusions. In addition, meta-analyses take the variance and sample size into account (giving more weight to studies with low variance and large sample size), as well as assess the magnitude of the mean effects (the effect size, Table 1) and analyse sources of variation among studies. This makes metaanalysis superior to methods that disregard the magnitude and precision of the effect, e.g. vote-counting. For vote-counting, researchers only count the number of studies finding significant positive results, significant negative results and non-significant results, and draw (sometimes erroneous) conclusions from this (Borenstein et al. 2009, Koricheva \& Gurevitch 2014, Koricheva et al. 2013). Meta-analysis has led to the development of systematic reviews. This is a type of review where researchers use explicit methods and protocols to search for and identify all studies investigating a particular question and then critically apprises these to find the studies that are possible and relevant to include in analyses. The data from these studies are then synthesised using meta-analysis (Pullin \& Stewart 2006).

Table 1 | Examples of some of the most common effect sizes used (especially within biology). Information based on Koricheva et al. 2013.

\begin{tabular}{|c|c|c|c|}
\hline Effect size & Effect size family & Formula & Use \\
\hline $\begin{array}{l}\text { Standardized } \\
\text { difference in } \\
\text { means }(d)\end{array}$ & Difference family & $\begin{array}{l}d=\bar{x}_{1}-\bar{x}_{2} / \sigma \\
\text { where } \bar{x} \text { is the mean and } \sigma \\
\text { is the standard deviation } \\
\text { based on either or both } \\
\text { populations }\end{array}$ & $\begin{array}{l}\text { Used to compare } \\
\text { means between } \\
\text { studies, where the } \\
\text { means have been } \\
\text { measured on different } \\
\text { scales }\end{array}$ \\
\hline $\begin{array}{l}\text { Response } \\
\text { ratio (RR) }\end{array}$ & Difference family & $\begin{array}{l}\ln R R=\ln \bar{x}_{1}-\ln \bar{x}_{2} \\
\text { where } \bar{x} \text { is the mean }\end{array}$ & $\begin{array}{l}\text { Used to compare the } \\
\text { ratio of two means }\end{array}$ \\
\hline $\begin{array}{l}\text { Odds ratio } \\
\text { (OR) }\end{array}$ & Categorical family & $\begin{array}{l}O R=A D / B C \\
\text { where } A \text { is the number of } \\
\text { responses of group } 1, B \text { is } \\
\text { the number of responses } \\
\text { of group } 2, C \text { is the } \\
\text { number of non-responses } \\
\text { in group } 1 \text { and } D \text { is the } \\
\text { number of non-responses } \\
\text { in group } 2\end{array}$ & $\begin{array}{l}\text { Used to compare the } \\
\text { ratio of the odds of an } \\
\text { event occurring in one } \\
\text { group relative to the } \\
\text { odds of the same event } \\
\text { occurring in the other } \\
\text { group }\end{array}$ \\
\hline $\begin{array}{l}\text { Pearson's } \\
\text { correlation } \\
\text { coefficient }(r)\end{array}$ & Correlation family & $\begin{array}{l}z=1 / 2 \ln (1+r / 1-r) \\
\text { where } z \text { is the Fisher's } z- \\
\text { transformation, and } r \text { is } \\
\text { the correlation coefficient }\end{array}$ & $\begin{array}{l}\text { Used for comparison of } \\
\text { the correlation between } \\
\text { two paired variables. } \\
\text { Usually transformed } \\
\text { using Fisher's z- } \\
\text { transformation. }\end{array}$ \\
\hline
\end{tabular}


The methods for meta-analysis were initially developed in medicine and various social sciences (O'Rourke 2007), e.g. to examine treatment effects on medical conditions on a large scale. Within ecology and evolutionary biology, metaanalysis was introduced as an analysis tool in the early 1990's and have since become increasingly more important due to the benefits of this analysis method. For example, in 2012 more than 40 meta-analyses were published in the field of plant biology alone (Koricheva \& Gurevitch 2014, Koricheva et al. 2013).

Despite the many strengths of meta-analysis, some things must be considered when performing meta-analyses. It is argued that meta-analysis should not be applied on too heterogeneous data, e.g. including studies with large differences in the experimental design or studies measuring effect on different response variables. The reason for this is the difficulty in drawing meaningful conclusions - unless the goal is to generalise across e.g. different species and/or ecosystems (Koricheva et al. 2013). Another problem is the fact that many primary studies do not report the essential data needed for meta-analyses, e.g. the variance or sample size. This often leads to study exclusion and potential loss of information. Other potential limitations are the presence of publication bias, which arises when relevant studies are not included for some reason or because statistically significant results are more likely to be published compared to studies finding no differences in effects; and the failure to test the robustness of the results using sensitivity analyses, which test the impact of individual studies on the overall results (the robustness is lower if one or a few studies highly influence the mean effect size) (Dwan et al. 2013, Koricheva \& Gurevitch 2014). However, these problems can be mitigated (see Koricheva \& Gurevitch (2014) for potential ways of overcoming lack of measures of variance or sample size, and e.g. Borenstein et al. (2009) for information on tests for publication bias and sensitivity analyses).

\subsubsection{Prospects of using meta-analysis when evaluating management effects in semi-natural grasslands}

Meta-analysis is useful to overcome the problems with primary studies comparing management effects on grassland biodiversity. This analysis method makes it possible to, e.g., simultaneously analyse several studies comparing management effects, for different types of grasslands, organisms and experimental designs, and arrive at more robust conclusions. Usually, management decisions for semi-natural grasslands are based on the personal experience of semi-natural grassland managers, and ideally also on information from primary studies investigating management effects. By basing these decisions on experience and results from studies using meta-analysis methods instead, it becomes possible to let more robust conclusions guide management choices (Pullin et al. 2004). In addition, evaluating a multitude of primary studies can prove a difficult and time-consuming task for the policy makers and managers responsible for deciding management plans. Therefore, reviews 
incorporating meta-analysis may be more time-efficient, especially if the reviews are aimed specifically towards policy-makers and managers (Milberg 2014).

There are a few examples of studies using meta-analysis methods to investigate management effects in semi-natural grasslands. Humbert et al. (2016) found negative effects of nitrogen addition on plant biodiversity in mountain grasslands, and Humbert et al. (2012) found that delaying mowing from spring to fall or early summer to later in the season had a negative effect on plant species, while delaying mowing generally had a positive effect on invertebrate species. Newton et al. (2009) found positive effects of grazing on lowland heathlands in north-western Europe. A review by Marriott et al. (2004) found more positive effects of low intensity management practices in upland areas (note that this study did not use meta-analysis methods). These examples suggest the potential usefulness of meta-analysis for finding the best available management method. 


\section{GENERAL AIMS}

The overall aim of this thesis was to use existing field trials and data to compare the effects of different management methods, and explore how efficient these are at preserving the biodiversity of semi-natural grasslands. In more detail, the aims were to:

I compare effects of grazing vs. mowing, different mowing frequencies and different mowing techniques on plant species, using data from field experiments performed in Swedish semi-natural grasslands (paper I-III),

II compare effects of grazing vs. mowing and different mowing frequencies on semi-natural grassland biodiversity, using studies from Europe and the rest of the world to reach more general and robust conclusions on management effects (paper IV and V),

III use the results to make management recommendations based on the method(s) with the most beneficial effects. 


\section{METHODS}

\subsection{Comparing management effects in Swedish semi-natural grasslands}

Paper I-III analysed data from two Swedish field experiments evaluating different management effects on the biodiversity, in one or eleven sites respectively. Paper I compared effects of different mowing techniques, paper II compared effects of grazing and mowing and paper III compared effects of annual mowing and mowing every third year.

\subsubsection{Study sites and experimental design}

The study site for paper I was Sättra ängar, a nature reserve located in the county of Östergötland, south-eastern Sweden (Figure 3-4). The experimental site was located in a meadow within the nature reserve which had been mowed since at least the $17^{\text {th }}$ century, but was used as a pasture between 1938 and the early 1970s. The experiment was established in 2001 in a part of the meadow that had been mowed annually since the 1970s using a scythe or a sickle bar mower. Three different mowing techniques were investigated, i) mowing using a sickle bar mower at a 5 -cm cutting height (control), ii) mowing using a grass trimmer at a 5 -cm cutting height and iii) mowing using a grass trimmer at a $\mathrm{O}-\mathrm{cm}$ cutting height. Treatment plots were $2 \times 4 \mathrm{~m}$, replicated five times per treatment. Mowing of each treatment took place in late July, with aftermath grazing by cattle or horses. Vegetation sampling took place before mowing in 2001-2005, 2008 and 2012, by recording the presence of vascular plant species in 40 permanent $10 \times 10 \mathrm{~cm}$ subplots per treatment plot. For more information, see paper I and Svensson et al. (2009).

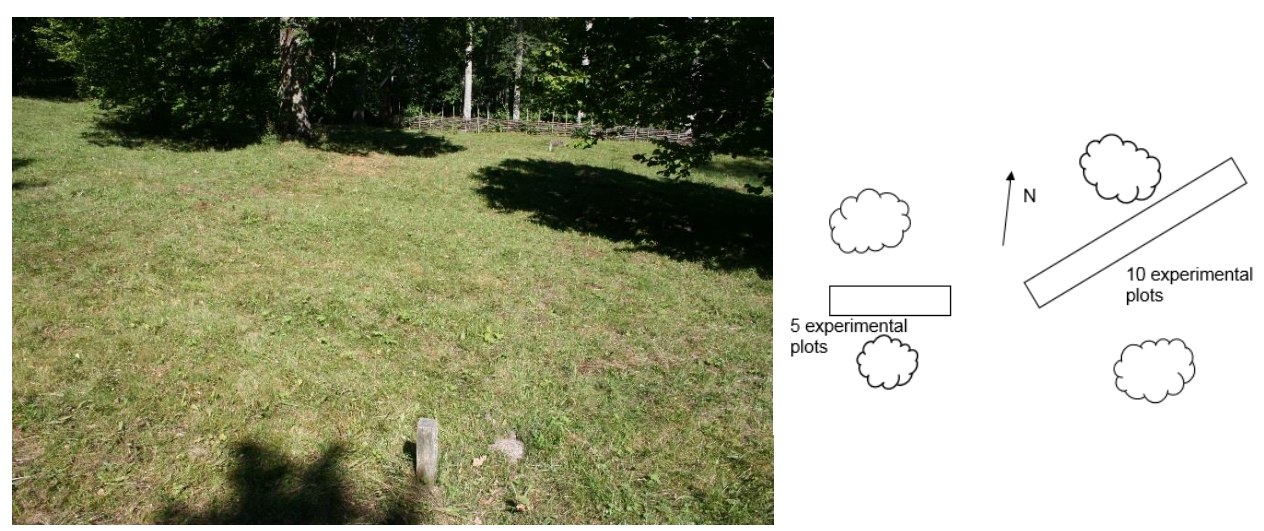

Figure 3 | The site and experimental layout used in paper I. Photo is of the ten eastern experimental plots, taken a few weeks after mowing in 2015. At that time, individual treatment plots could not be distinguished by eye. Photo: Per Milberg. Line drawing: Malin Tälle 
The study sites for paper II and III were situated at nine locations in southern Sweden, with two locations having two experimental sites each (Figure 4). These sites had different soil type and land-use history, contained different plant communities and had differing productivity. The management experiment in these sites were started in the 1970s, with the aim of comparing effects of seven different management methods. Paper II and III focused on four of these, namely grazing, annual mowing, mowing every third year and abandonment (control). These management methods were applied to $5 \mathrm{x} 20 \mathrm{~m}$ treatment plots, replicated two times per treatment and site. Plots with grazing were mainly grazed by cattle, but also sheep or horses, at varying grazing intensities. Plots with mowing were cut in late July or early August, using scythes or sickle bar mowers. Vegetation sampling took place before mowing, recording the presence or cover of vascular plant species in five permanent subplots per treatment plot, although the number of subplots differed somewhat between years and sites. For a majority of sites the sampling occurred three times, at the start of the experiment in the early 1970s, in 1980 and in 1986, when financing of the management experiment ended. However, for some sites, sampling only took place at the start and end of the experiment. For more information see paper II, III and Hansson (1991).
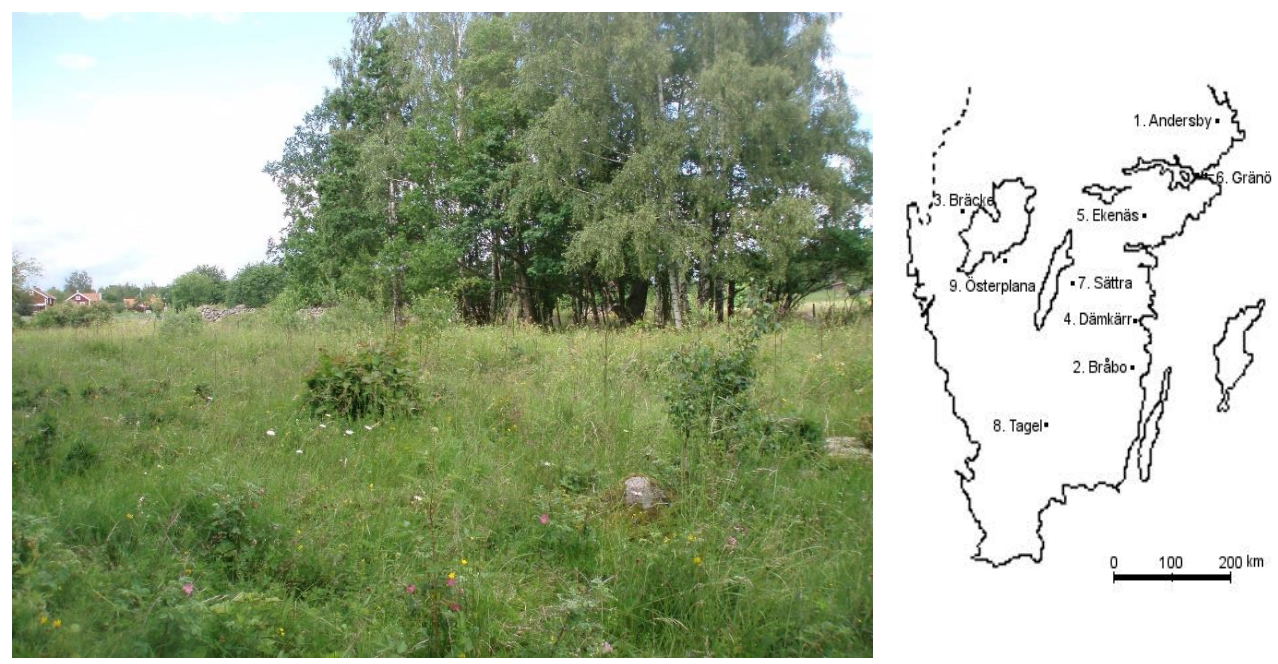

Figure 4 | Location of the study sites used in paper II and III. Ekenäs and Tagel had two experimental sites each. The Sättra site was located within the same nature reserve as the site investigated in paper I. The photo is of the Bråbo site in 2012, when some of the management methods were still applied. Trees in the background are in the control plot, while plots with annual mowing are in the foreground. Photo and map: Malin Tälle. 


\subsubsection{Analysis methods}

For paper I-III meta-analysis methods were used to analyse the data. This was mainly to facilitate analyses of data collected in different years (paper I) or across sites where slightly different experimental designs and survey methods were used (paper II and III), and to follow the development of the vegetation for the different management methods over time. Meta-analyses for all papers were performed using the meta-analysis tool Comprehensive Meta-analysis version 2 (Biostat Inc. 2006). For more information on the analysis methods used, see the respective paper.

For paper I and II the focus of the analyses were the effects of the different management methods on the occurrence of plant indicator species. Several different Swedish indicator systems were used (Table 2), categorizing species as indicators of i) good management for species richness, ii) poor management or iii) excess nitrogen. The occurrence of the indicator species in the different treatments were analysed using odds ratios (see Table 1). The best management method for the preservation of biodiversity were consider the one resulting in high odds of finding indicators of good management for species richness and low odds of finding indicators of poor management and excess nitrogen. Paper I also investigated management effects over time by performing a Principle Response Curve analysis using the software CANOCO 5 (ter Braak \& Šmilauer 2012), with time and mowing technique used as explanatory variables.

Paper III included meta-analyses of the effects of the two mowing frequencies on the odds of finding indicator species, similar as for paper I and II. In addition, this paper investigated the effects of the mowing frequencies and the unmanaged control on the plant species richness and diversity, using the response ratio (see Table 1). Paper III also investigated species-wise responses to the treatments, to explore how the occurrence of individual species differed for the different treatments, and included comparisons of mowing every third year and the unmanaged control.

\subsection{Comparing management effects reported in the literature}

Paper IV and V systematically reviewed published studies comparing effects of grazing and mowing or different mowing frequencies on both flora and fauna in semi-natural grasslands, and used meta-analysis to analyse the data that was found. For both papers the literature was systematically reviewed using similar, pre-determined protocols. For more information on the methods used, see the respective paper.

\subsubsection{Retrieving the data}

Studies comparing grazing and mowing or the different mowing frequencies (annual mowing vs. mowing every fifth, third or second year and mowing two, three of four times per year) were searched for in the databases Scopus, 
Table 2 | Description of the indicator systems used for paper I-III

\begin{tabular}{|c|c|c|c|}
\hline Indicator system & Description & Indicator types & Included in \\
\hline $\begin{array}{l}\text { Bertilsson \& Paltto } \\
(2003)\end{array}$ & $\begin{array}{l}\text { Regional indicator system } \\
\text { developed for the province of } \\
\text { Västergötland, south-western } \\
\text { Sweden, for the evaluation of } \\
\text { the grazing management } \\
\text { status in semi-natural } \\
\text { grasslands }\end{array}$ & $\begin{array}{l}\text { Good management } \\
\text { for species richness, } \\
\text { Poor management, } \\
\text { Excess nitrogen }\end{array}$ & Paper I, II \\
\hline $\begin{array}{l}\text { Ekstam \& Forshed } \\
\text { (1992) }\end{array}$ & $\begin{array}{l}\text { Classifies Swedish plant } \\
\text { species according to the rate } \\
\text { at which they are lost during } \\
\text { secondary succession and } \\
\text { their preference for nitrogen } \\
\text { availability. E.g. indicators of } \\
\text { Good management for species } \\
\text { richness disappears early in } \\
\text { succession and grows in sites } \\
\text { poor in nitrogen. }\end{array}$ & $\begin{array}{l}\text { Good management } \\
\text { for species richness, } \\
\text { Poor management, } \\
\text { Excess nitrogen }\end{array}$ & Paper I-III \\
\hline $\begin{array}{l}\text { Larsson \& Ekstam } \\
\text { (1987) }\end{array}$ & $\begin{array}{l}\text { Developed to assist in the } \\
\text { development of a Swedish } \\
\text { national inventory of semi- } \\
\text { natural grasslands }\end{array}$ & $\begin{array}{l}\text { Good management } \\
\text { for species richness }\end{array}$ & Paper I \\
\hline $\begin{array}{l}\text { Swedish EPA } \\
\text { (Naturvårdsverket, } \\
\text { 2011) }\end{array}$ & $\begin{array}{l}\text { Based on the species listed as } \\
\text { defining seven different } \\
\text { Swedish grassland types in } \\
\text { Natura } 2000, \text { according to the } \\
\text { Swedish Environmental } \\
\text { Protection Agency }\end{array}$ & $\begin{array}{l}\text { Good management } \\
\text { for species richness }\end{array}$ & Paper I \\
\hline
\end{tabular}

Biological Sciences, Biological Abstracts and Agricola, using specific search terms (Table 3). Both papers used similar criteria when determining which studies to include. For example, only studies examining an outcome relevant for the conservation of biodiversity in semi-natural grasslands were included in analyses (e.g. excluding studies focusing on biomass production) as well as studies where the desired outcome was clear from a conservation viewpoint (e.g. including studies reporting mean species richness but excluding studies reporting on mean soil nitrogen content). Furthermore, the included studies had to present data in the form of estimates with variance and sample size. Paper IV included studies performed all over the world while paper $\mathrm{V}$ only included studies performed in Europe. For each included study, data and information on study characteristics like grassland type, altitude and previous management were compiled. 


\subsubsection{Analysis methods}

Paper IV analysed data from 35 studies, comparing the standardized difference in means between treatments. For paper V, data from 29 studies were analysed, using the response ratio to compare effects between treatments (see Table 1). However, to avoid bias due to small sample sizes, Lajeunesse's (2015) method for calculating response ratios was used. Both papers used random effects models, where the weights given to the individual studies in the analyses are based on both within and between study variance (Borenstein et al. 2009). The effects were analysed including all studies, and with studies grouped based on explanatory variables, where studies with similar characteristics were analysed together (Table 3). For both papers, sensitivity analyses were performed to test the robustness of the conclusions, by assessing the impact of individual studies on the combined effect. If any study has a large impact on the results compared

Table 3 | The search terms used for the literature search in paper IV-V. * indicates a wildcard.

\begin{tabular}{|c|c|c|c|}
\hline Study & Comparison & Search terms & Explanatory variables \\
\hline Paper IV & $\begin{array}{l}\text { Grazing vs. } \\
\text { mowing }\end{array}$ & $\begin{array}{l}\text { mow* OR scythe* AND }^{*} \text { graz* AND }^{*} \\
\text { grassland* OR meadow* OR } \\
\text { pasture* OR fen* OR heath* }^{*}\end{array}$ & $\begin{array}{l}\text { Altitude, Geography, } \\
\text { Grassland type, Grazer } \\
\text { type, Mowing date, } \\
\text { Treatment used, Use of } \\
\text { fertilizers, Historical } \\
\text { management, Recent } \\
\text { management, Organism, } \\
\text { Outcome, Data type, Study } \\
\text { length, Study quality }\end{array}$ \\
\hline Paper V & $\begin{array}{l}\text { Annual mowing } \\
\text { vs. mowing } \\
\text { every } 5^{\text {th }}, 3^{\text {rd }} \text { or } \\
2^{\text {nd }} \text { year and } 2,3 \\
\text { or } 4 \text { times a } \\
\text { year }\end{array}$ & $\begin{array}{l}\text { Mow* OR hay* OR scythe* } \\
\text { OR harvest* OR cut* AND } \\
\text { frequenc* OR intensit" OR } \\
\text { regime* OR month* OR } \\
\text { "every other" OR "every } \\
\text { second" OR "every third" OR } \\
\text { "mow* time" OR "mow* date" } \\
\text { OR "harvest* date" OR "hay" } \\
\text { time" OR "cut* date" OR "cut* } \\
\text { time" OR season* OR } \\
\text { interval* AND } \\
\text { grassland* OR meadow* OR } \\
\text { fen* OR heath* OR wetland* } \\
\text { OR marsh* OR bog* OR } \\
\text { reed* AND } \\
\text { management }\end{array}$ & $\begin{array}{l}\text { Altitude, Contintentality, } \\
\text { Geography, Grassland type, } \\
\text { Length of growing season, } \\
\text { Soil moisture, Historical } \\
\text { management, Recent } \\
\text { management, Organism, } \\
\text { Outcome, Study length }\end{array}$ \\
\hline
\end{tabular}


to other studies the robustness is considered low (Philibert et al. 2012). Both papers also investigated the presence of publication bias using Egger's regression asymmetry test (Egger et al. 1997). Publication bias arises when published work is more likely to be positive or statistically significant than unpublished results, leading to an over-estimation of management effects (Dwan et al. 2013). 


\section{SUMMARY OF PAPERS}

Paper I: Mowing for biodiversity: grass trimmer and knife mower perform equally well

Background and aim

Mowing using mechanical instruments that cut the vegetation, e.g. sickle bar mowers, is considered superior to mechanical instruments that tears off the plant material, e.g. grass trimmers. However, almost no studies have compared the effects of these mowing techniques on grassland vegetation. Using a 11-year field experiment performed in a Swedish semi-natural grassland, the aim of paper I was to compare effects of mowing using a sickle bar mower and a grass trimmer at a $5-\mathrm{cm}$ and $\mathrm{o}-\mathrm{cm}$ cutting height. Effects were examined on the plant species richness and the odds of finding plant indicator species of i) good management for species richness, ii) poor management and iii) excess nitrogen, based on four Swedish indicator systems. In addition, differences in effects over time were examined using a Principle Response Curve.

Results and conclusions

Over time, there was no difference in the odds of finding indicators of any type, for any of the mowing techniques. In addition, there was only small effects on the number of plant species, and the Principle Response Curve did not reveal any differences in effects between mowing techniques. This suggests that there is a similar effect of mowing using a sickle bar mower and grass trimmer on the floristic composition of semi-natural grasslands. 
Paper II: The conservation benefit of mowing vs grazing for management of species-rich grasslands: a multi-site, multi-year field experiment

Background and aim

Management methods like grazing or mowing are needed to preserve seminatural grasslands, but as management is costly and funds are limited it is important to use the most beneficial management method. Using a long-term Swedish field experiment performed in eleven different grassland sites, the aim of paper II was to compare the effect of grazing and mowing. Effects were examined on the odds of finding plant indicator species of i) good management for species richness, ii) poor management and iii) excess nitrogen, based on two Swedish indicator systems. In addition, this paper also compared the effect of grazing at different intensities with mowing.

Results and conclusions

There was an increase in the odds of finding indicators of good management for species richness in mowed plots and an increase in the odds if finding indicators of excess nitrogen in grazed plots. There was a more negative effect of grazing when using a "low" compared to a "normal" grazing intensity. This suggest that mowing is a better long-term management method compared to grazing in Swedish semi-natural grasslands and that a low grazing intensity should be avoided. 
Paper III: The biodiversity cost of reducing management intensity in species-rich grasslands: mowing annually vs. every third year

Background and aim

Mowing is an important management method for semi-natural grasslands. As it is costly to perform it is important to investigate the biodiversity benefits of different mowing frequencies. Using a Swedish field experiment performed in eleven grassland sites, the aim of paper III was to compare the effect of annual mowing and mowing every third year. Effects were investigated on the plant community and plant diversity and the odds of finding plant indicator species of i) good management for species richness and ii) poor management.

Results and conclusions

Mowing every third year resulted in a small drop in plant species richness and diversity, with a majority of species occurring less frequently with this treatment (with the exception of woody species). However, there was no difference in the odds of finding indicators of good management for species richness or poor management between the mowing frequencies. When comparing mowing every third year to the unmanaged control, the loss of biodiversity was about half as large when mowing every third year. This suggests that annual mowing has a more positive effect, but as the differences were relatively small between frequencies, mowing every third year could still be a viable management option that is potentially more cost-effective. 
Paper IV: Grazing vs. mowing: a meta-analysis of biodiversity benefits for grassland management

Background and aims

Most studies comparing effects of grazing and mowing have a limited scope, e.g. only investigating effects in one grassland or for one type of organism. Therefore, it is difficult to reach more general and robust conclusions and give useful management recommendations. Using meta-analysis to analyse the results of many studies at once is a way to mitigate these difficulties. In paper IV, the aim was to systematically review studies comparing effects of grazing and mowing on the flora and fauna of semi-natural grasslands and analyse the data using meta-analysis.

Results and conclusions

In total, 35 studies from all over the world involving 148 response variables, was included in the analyses and the results revealed a slightly more positive effect of grazing compared to mowing on the biodiversity of semi-natural grasslands, but the differences between treatments were small. Results varied for different grassland characteristics such as geography, grassland type and previous management, with grazing and mowing having a similar effect or mowing having a more positive effect in certain cases. These results suggest that specific grassland conditions should be considered when determining the most suitable management method, but that generally, grazing should be the preferred management method in semi-natural grasslands. 
Paper V: Similar effects of different mowing frequencies on the conservation value of semi-natural grasslands in Europe

Background and aim

The evaluation and comparison of effects of different management intensities on a larger scale is often challenging. Hence, there are few conclusive results from studies examining effects of different mowing frequencies across Europe. In paper $\mathrm{V}$ studies comparing effects of annual mowing with mowing every fifth, third or second year or mowing two, three or four times a year on semi-natural grassland flora and fauna was systematically reviewed and analysed using metaanalysis.

Results and conclusions

In total, 29 European studies involving 117 response variables were included in the analyses and the results revealed a more positive effect of more frequent mowing. However, the differences in effects between mowing frequencies were small and with varying results for different grassland characteristics. For example, a higher mowing frequency was mostly better in more productive grasslands. These results suggest that mowing less frequently, e.g. every other year, can be a viable management method in less productive semi-natural grasslands, and a way of using the limited funds available for management more efficiently. 


\section{DISCUSSION}

Management is vital for the preservation of semi-natural grasslands (e.g. Klimek et al. 2007), but the funds available for management through e.g. grazing and mowing are limited. To recommend a management method for use in seminatural grasslands, it is therefore important that it preserves the high diversity of the plant and animal species that depend on this habitat type over a long time period. In addition, a recommended management method should maintain a community rich of desired species and disfavour undesired species (e.g. invasive species or species that are fast growing, nutrient demanding and strong light competitors). Paper I-V used data from Swedish experimental trials and studies from Europe and the rest of the world, to compare management effects on different types of organisms and in different types of grasslands, with the aim of developing specific management recommendations.

\subsection{Effects of mowing techniques}

Among conservation managers, using mowing techniques that tears the plant material (e.g. grass trimmers) is considered inferior to using techniques that cut the vegetation (e.g. scythe or sickle bar mower) (Ekstam et al. 1988, Sandberg \& Thylén 1999). The results from paper I could not confirm these perceived negative effects of mowing using a grass trimmer compared to a sickle bar mower, even when using a very low cutting height $(0 \mathrm{~cm})$. Analyses revealed no change in the odds of finding any indicator species (Figure 5) and only small changes in the plant species richness, regardless of the mowing technique used.

One crucial aspect of mowing is the removal of the cut material, as this removal helps maintain the low nutrient conditions that benefit diverse semi-natural grasslands and helps prevent the accumulation of litter (Oelmann et al. 2009). It is possible that the perceived negative effects of mowing using a grass trimmer emerged from cases where the cut material was not removed after mowing, which is known to have a negative effect on the vegetation (Loydi et al. 2013, Ruprecht et al. 2010, Schreiber et al. 2009). Another reason could be the difficulty in actually removing the fragmented plant material resulting from mowing using a grass trimmer. However, if this is the case, it is unclear if enough plant material is left to cause vegetation changes, as negative effects of remnant litter on biodiversity only occurs at relatively high litter densities (Kelemen et al. 2014, Loydi et al. 2013). Besides, the odds of finding indicators of poor management and excess nitrogen were unchanged over time in paper I, indicating no significant accumulation of litter.

It is important to note that the field experiment in paper I was performed in a grassland that had been managed using mainly mowing for a very long time. Hence, it already had a species rich vegetation with indicator species for wellmanaged grasslands. It is possible that effects of mowing using a grass trimmer 
or sickle bar mower may differ in newly restored grasslands without a desired vegetation composition. Mowing using a grass trimmer could still be useful during restoration, as it facilitates easier removal of the woody and tall-grown vegetation that results from abandonment (Ekstam et al. 1988).
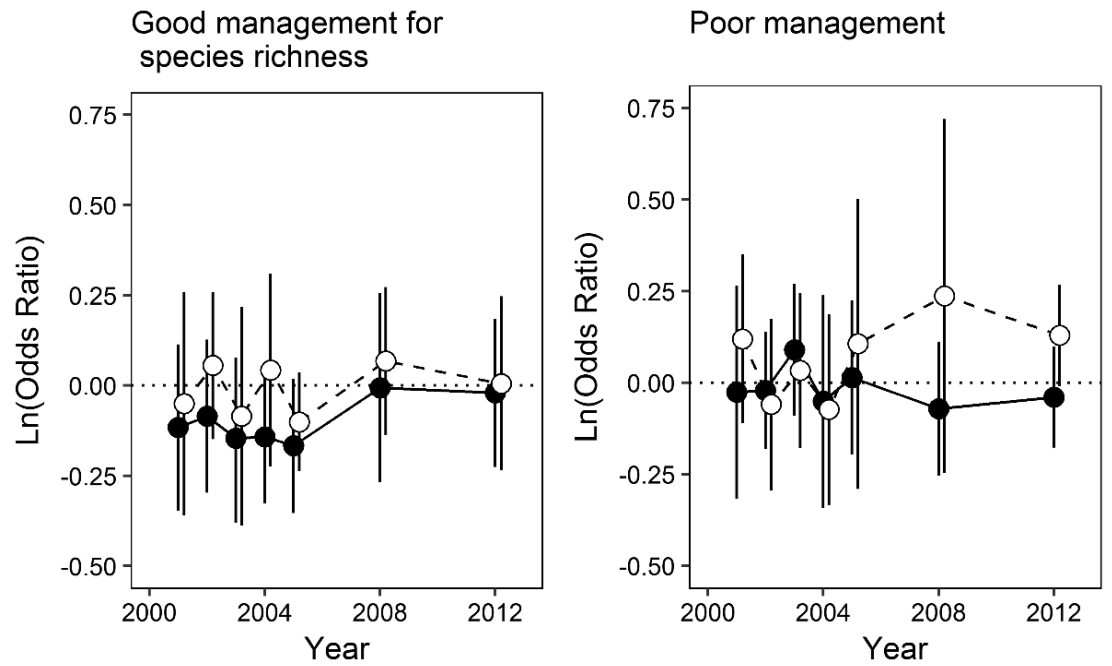

Figure 5 | Change in $\ln$ (odds ratio) $\left(\mathrm{CI}_{95 \%}\right)$ of plant indicator species of good management for species richness and poor management in a Swedish field experiment (paper I), when mowing using sickle bar mower or grass trimmer. Filled symbols represent mowing with a grass trimmer at $5 \mathrm{~cm}$, open symbols mowing at $0 \mathrm{~cm}$. A positive value signifies higher odds of finding indicators when mowing using sickle bar mower, a negative value signifies higher odds when mowing using grass trimmer. The indicators are based on Ekstam and Forshed (1992) (see Table 2).

\subsection{Effects of grazing vs. mowing}

Previous studies comparing effects of grazing and mowing on plant or animal species have found varying results, with some in favour of grazing and others in favour of mowing (e.g. Bonari et al. 2017, Catorci et al. 2014, Kahmen et al. 2002, Radlmair \& Laußmann 1997, Saarinen \& Jantunen 2005, Schläpfer et al. 1998). In paper II, meta-analyses of data from eleven Swedish semi-natural grasslands revealed a more positive effect of mowing compared to grazing, as the odds of finding indicators of good management for species richness increased with mowing while the odds of finding indicators of excess nitrogen increased with grazing (Figure 6). In paper IV, the meta-analyses of data from 35 different studies revealed a more positive effect of grazing on biodiversity. Hence, the results between the two papers seem contradictory. 


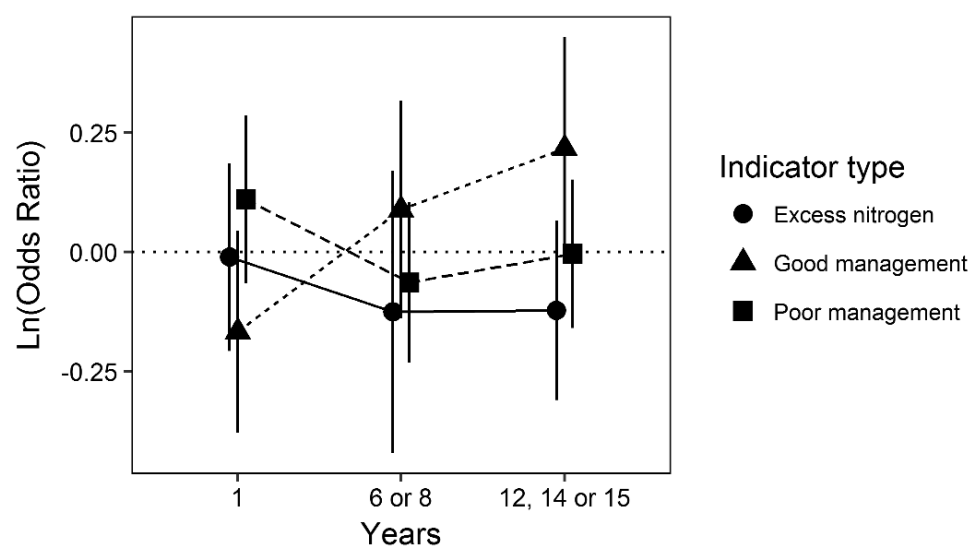

Figure 6 | Change in $\ln$ (odds ratio) $\left(\mathrm{CI}_{95} \%\right.$ ) of plant indicator species when comparing grazing and mowing in a Swedish field experiment performed in 11 grasslands (paper II). A positive value signifies higher odds of finding indicators with mowing, a negative value signifies higher odds with grazing. The indicators are based on Ekstam and Forshed (1992) (see Table 2).

The mechanisms involved in the varying effects of grazing and mowing found in previous studies and in paper II and IV are unclear. It is possible that the treatments may have different, positive or negative, effects depending on e.g. the grassland characteristics or organism type. For example, some species traits are favoured by the selective nature of grazing (e.g. prickliness or poisonousness), while others are favoured by mowing (e.g. depressed rosette leaves, late flowering and seed set) (Catorci et al. 2011, Chaudron et al. 2016, Moretto \& Distel 1999, Rook et al. 2004). Grazing is generally more gradual and non-intrusive compared to mowing (Oates 1995) and creates more spatially heterogeneous vegetation (Adler et al. 2001, Olff \& Ritchie 1998), which may promote biodiversity (see Box 1). The homogenous plant community resulting from mowing may decrease species competition and result in increased species evenness (Fischer \& Wipf 2002, Lepš 2014). Grazing facilitates the recycling of nutrients through dung and urine and increases the turnover of nutrients, thereby affecting the vegetation (De Mazancourt et al. 1988, Lepš 1995), and the removal of all flowering plants at once through mowing may negatively affect nectar-feeding insects (Milberg et al. 2016). Therefore, varying effects across different studies are not that surprising.

It is important to note that for paper II and IV, the difference between treatments were actually quite small. For paper II, the maximum change in $\ln$ (odds ratio) was 0.4 , which corresponds to a standardized difference in means of 0.22 , while for paper IV, the difference in means was generally around 0.15 . A standardized difference in means below 0.3 is considered a small difference 
in effects between treatments (Cohen 1992). In addition, paper II measured effects on plant indicator species while paper IV measured effects on plant and animal species diversity. In fact, in paper II the mean plant species richness per $5 \mathrm{~m}^{2}$ decreased over ca. 15 years, from $49.91 \pm 14.26$ to $48.09 \pm 15.84$ for grazing and $46.91 \pm 14.47$ to $45.64 \pm 16.46$ for mowing (mean $\pm \mathrm{SD}$ ), indicating that there is a similar effect of grazing and mowing on species richness over time. In other words, effects of grazing and mowing were actually quite similar in the two papers. This is probably, at least in part, due to the combination of positive and negative effects of the management methods, which in this case resulted in overall neutral effects.

Paper II also compared the effects of different grazing intensities (low vs. normal/high) to annual mowing. Analyses revealed a more negative effect of a low grazing intensity compared to mowing, while a normal/high grazing intensity had a similar positive effect as annual mowing. This is in accordance with the intermediate disturbance hypothesis (see Box 1) and may be an effect of tall-grown species limiting e.g. light availability when grazing at a low intensity (Einarsson \& Milberg 1999, Golodets et al. 2010). In contrast, results from previous studies have revealed a more positive effect of both a low and a normal/moderate grazing intensity (Stewart \& Pullin 2008, Török et al. 2016, Yang et al. 2006). One potential reason for this contrast in effects compared to previous studies (aside from differing study design and grassland conditions) might be that the classification of the grazing intensity in paper II is based on the subjective assessment of the fieldworker who visited all experimental sites and was not based on the livestock number or grassland productivity (Hansson 1991). It might therefore be difficult to directly compare the results from paper II with other studies, as the estimation of the grazing intensity depends on e.g. grassland productivity. To facilitate comparisons between studies, a measure of grazing intensity that is more valid and reliable would be welcome, i.e. a measure that is consistent and accurate (Golafshani 2003) for different grassland conditions and animal types and that takes grassland productivity into account. One possibility is using livestock units (LU) to categorise the grazing intensity, which expresses the number of animals of different age or size that can be sustained in a certain grassland area. For example, a 10 ha grassland that can sustain 15 dairy cows or 100 medium sized sheep have a LU of 1.5 per ha (Chesterton 2006). However, it might still be difficult to evaluate what constitutes a too low or high grazing intensity, if LU is only presented to specify the number of animals per ha in an area, and not actually the number of animals that can be sustained in that area.

Paper IV compared the overall effect of grazing and mowing, but also focused on the effects depending on different explanatory variables, with varying results for different grassland characteristics (Figure 7). It is important to consider that for the analyses of the effects of different characteristics (so called explanatory 
variables), only a low number of studies could be included in analyses. In addition, results for some of these explanatory variables may be confounded. For example, the positive effect of grazing in some dry grasslands might not result from the dry conditions, but actually be an effect of the fact that dry grasslands have traditionally seldom been cut (Dolek \& Geyer 2002); and the effect of management on the outcome measured might be connected to the organisms measured, e.g. as effects on biomass was only measured for earthworms. Since effects differed for different explanatory variables, it is important to consider specific grassland conditions when making management recommendations.

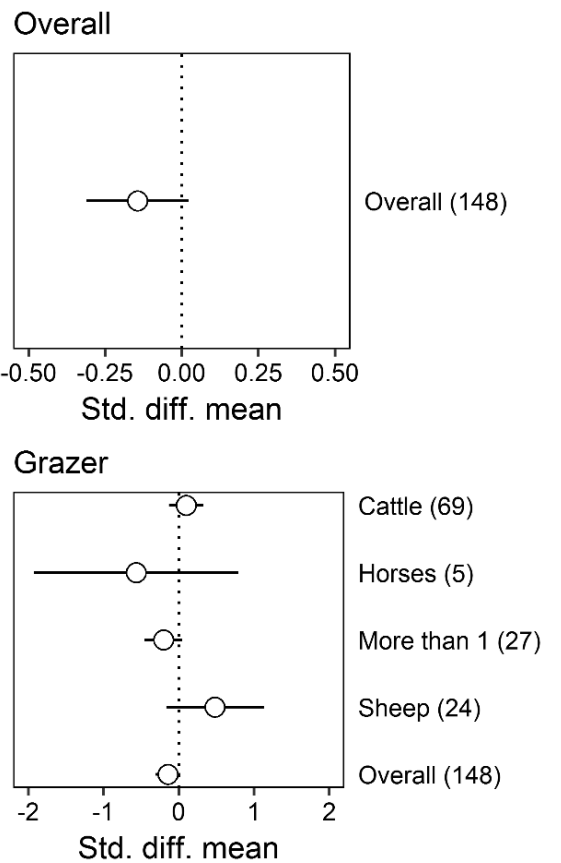

Figure 7 | Standardized difference in means $\left(\mathrm{CI}_{95 \%}\right)$ for the comparison of grazing vs. mowing based on meta-analysis of 35 studies (paper IV). A negative value signifies more positive effects of grazing and a positive value signifies more positive effects of mowing. Overall effects when including all studies and effects when grouping studies based on the grazer or vegetation type used. Numbers in parentheses are the number of response variables included in the analyses for each class. 


\subsection{Effects of different mowing frequencies}

Studies investigating effects of different mowing frequencies on grassland biodiversity have found results in favour of mowing at least two times a year, annual mowing and less frequent cuts (e.g. Jantunen et al. 2007, Noordjik et al. 2009, Ryser et al. 1995). In paper III, data from eleven Swedish field experiments revealed that annual mowing had a more positive effect on species richness and diversity and the majority of individual plant species, compared to mowing every third year. When comparing mowing every third year and abandonment, it was revealed that the loss of biodiversity was about half as large when mowing every third year. However, the differences between mowing frequencies over time were quite small. The $\ln$ (response ratio) rarely exceeded 0.1, which is the equivalent of comparing a species richness of 20 and 22 species. In addition, the odds of finding indicators of good management for species richness and poor management were similar between the treatments (Figure 8). In other words, the richness and abundance of species may have changed some over time, but the vegetation composition remained quite similar. In paper V,
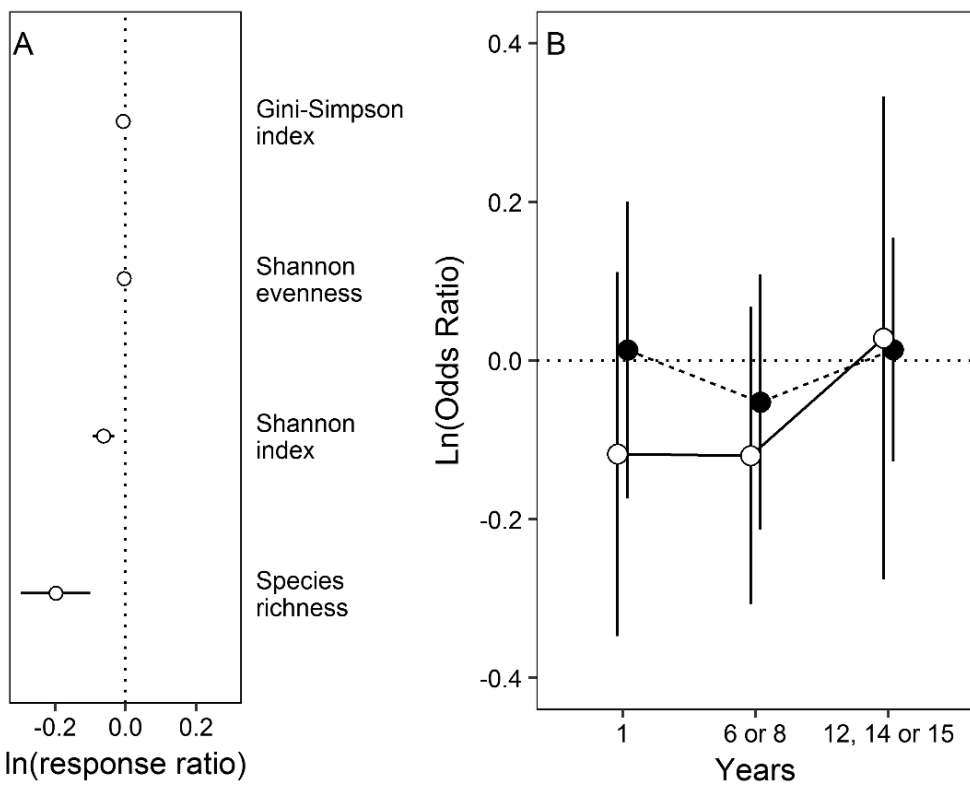

Indicator type

$\bigcirc$ Good management

- Poor management

Figure 8 A) $\ln$ (response ratio) $\left(\mathrm{CI}_{95 \%}\right.$ ) for species richness and other diversity measures and $\mathrm{B}$ ) change in $\ln$ (odds ratio) $\left(\mathrm{CI}_{95 \%}\right)$ of plant indicator species, when comparing annual mowing and mowing every third year in a Swedish field experiment performed in eleven grasslands (paper III). In A) a negative value signifies a more positive effect with annual mowing, in B) a negative value signifies higher odds of finding indicators with mowing every third year. 
the meta-analyses of data from 29 European studies revealed only small differences in effects across the investigated mowing frequencies. However, it was generally the case that a higher mowing frequency was better in more productive grasslands, e.g. grasslands with longer growing season, wet grasslands and grassland with a previously high management intensity (e.g. with previous application of fertilizers) (Figure 9), which is something that can be expected based on literature (e.g. Fay et al. 2008, Karlík \& Poschlod 2014, Park et al. 2016). Thus, both paper III and V suggest only small differences between mowing frequencies.

The surprisingly minor differences in effects of different mowing frequencies probably has a few different reasons. Effects of mowing at a lower mowing frequency may be negative, as this may impair the seed generation and/or plant growth due to a denser canopy or higher litter accumulation (Kelemen et al.
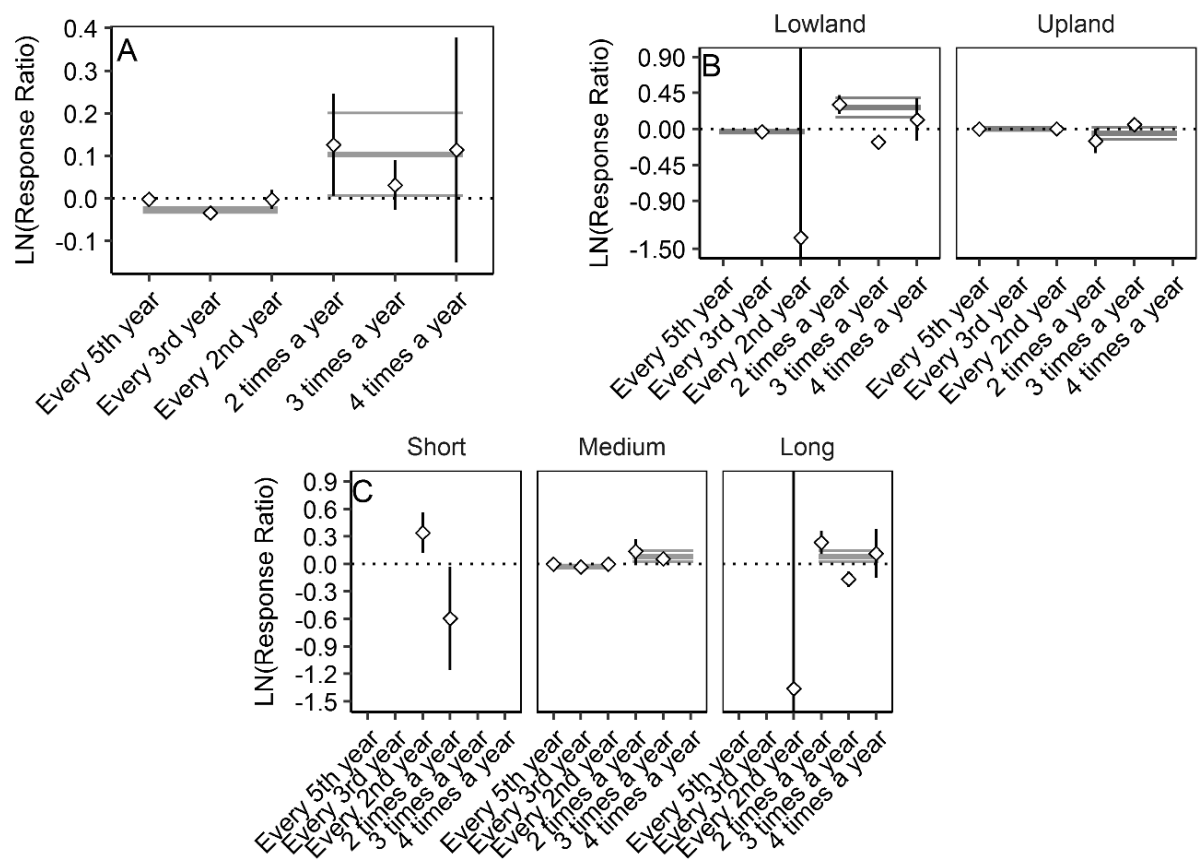

Figure $9 \mid \mathrm{Ln}$ (response ratio) $\left(\mathrm{CI}_{95 \%}\right)$ for the comparison of six different mowing frequencies to annual mowing, based on meta-analysis of 29 studies (paper V). A negative value signifies a more positive effect of annual mowing and a positive value signifies a more positive effect of the respective mowing frequency. Grey lines represent the $\ln$ (response ratio) $\left(\mathrm{CI}_{95 \%}\right)$ when analysing less frequent mowing than once per year or more frequent mowing than once per year together. A) is the overall effects, B) is effects when grouping studies based on the altitude of the study site and C) is effects when grouping based on the growing season in the study area. 
2013, Loydi et al. 2013), or increase competition from tall-grown species (Kiær et al. 2013, Lamb et al. 2009). Mowing at a higher mowing frequency can also be expected to have some negative effects, as it might supress the flowering and seed set of certain species (Kahmen \& Poschlod 2008, Poschlod et al. 2011). It is also possible that a lower or higher mowing frequency only marginally affects e.g. species richness, while still influencing e.g. species abundance, or that these treatments causes grassland specialist to be replaced by generalists. However, this did not seem to be the case based on the results from paper III and V, e.g. as the odds of finding indicators of good management for species richness and poor management remained unchanged. It is important to note that some previous studies have found little effect of management intensity. For example, Batáry et al. (2010) found no effect of management intensity on species number and abundance of bees and insect-pollinated plants and Dicks et al. (2017) found mostly positive to neutral effects of decreased management intensity in a number of European studies, indicating that similar effects of different mowing frequencies are not that unexpected.

The conclusions from paper III should be interpreted together with the fact that this paper focused on plant species. For example, relaxed management intensities have been found to be beneficial for many nectar-feeding insects (Littlewood et al. 2012, van Klink et al. 2015) as well as e.g. ground beetles and spiders (Cizek et al. 2012). Nevertheless, paper $V$ actually found a trend towards a more positive effect of mowing twice a year on insects. Thus, the conservation aim (e.g. plants vs. insects) must be considered when making management recommendations.

\subsection{The robustness of the conclusions}

As evident from the effect sizes calculated in the papers included in this thesis, the difference in effects between the management methods were quite small, especially when considering the overall mean effect sizes. However, one important consideration is also the robustness of the results and how this impacts the conclusions. The experimental trials in paper I-III ran for a relatively long time (over ten years) and for paper II and III the trials ran across eleven different grassland sites. In addition, paper IV and V included 35 and 29 studies respectively, which is considered an intermediate number of studies to include in meta-analysis (Philibert et al. 2012). Sensitivity analyses are an important part of meta-analyses in systematic reviews to test the robustness of results to assumptions and decisions made in the analysis (Koricheva \& Gurevitch 2014). Sensitivity analyses in paper IV and V revealed that no study, response variable or explanatory variable had any unjustifiably large impact on the results. 
The aim of this thesis was not to evaluate the use of meta-analysis to investigate management effects in semi-natural grasslands. Nevertheless, it turned out that meta-analysis was helpful in synthesising results and enable comparisons across different grassland sites or studies. For example, due to the nature of the data used in paper II and III it would have been more difficult to evaluate management effects without using meta-analysis, as conditions and to some extent also experimental design differed between sites. This was evident from e.g. paper III, where effects of mowing frequencies differed between sites (Figure 10). Thus, it may be problematic to base general conclusions on only a single study, which may have low generalisability. Without meta-analysis it would also have been impossible to reach more general conclusions based on the many studies included in paper IV and V.

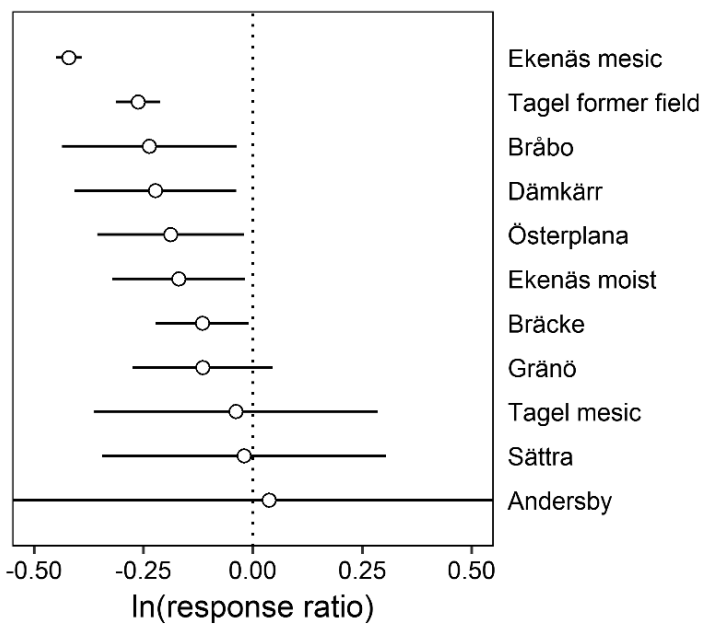

Figure 10 $\mid \operatorname{Ln}$ (response ratio) $\left(\mathrm{CI}_{95} \%\right)$ for the number of species in paper III. A negative value signifies lower species richness with mowing every third year compared to annual mowing. Note the difference in effects across the sites.

However, it is also important to consider the potential pitfalls when using metaanalysis to investigate general management effects. One such consideration is the presence of bias in some form. This can be publications bias, which may arise when relevant studies are excluded from analyses for some reason (e.g. as studies with non-significant results are less likely to be published, or that studies does not present usable data) (Dwan et al. 2013). No presence of publication bias was found in paper IV or V. Another form is spatial bias, which arise when it is more likely that studies from certain areas are included in meta-analyses. Most often this type of bias is a consequence of more studies being performed in more economically developed countries or continents (e.g. Europe or North 
America). The presence of this type of bias makes it less relevant to draw conclusions on e.g. a global scale (Gonzalez et al. 2016). In paper IV and V, this type of bias was probably present, as the global meta-analysis in paper IV mostly included studies from Europe, while the European meta-analysis in paper V mostly included studies from Western Europe. Thus, when drawing conclusions and making management recommendations based on these papers, it is probably more useful to focus on effects for specific grassland conditions compared to the overall effect. The length of studies is another type of bias that needs to be considered (Gonzalez et al. 2016). Many studies investigating management effects in semi-natural grasslands are of relatively short duration, often below ten years, at the same time as it is expected that changes due to e.g. management effects will take a long time to become evident (Milberg et al. 2014, Tilman et al. 1994), potentially leading to erroneous conclusions. Analyses in paper IV and V revealed differing management effects over time (e.g. a more positive effect of mowing compared to grazing over time in paper IV), which should be considered when drawing conclusions.

Together, the length of the studies in paper I-III, the number of studies included in paper IV and V and the sensitivity analyses performed, indicate that any substantial differences between management methods would be evident in the results. However, while the general conclusions in paper IV and V may be valid, the presence of bias and the fact that effects differed depending on e.g. grassland type and organism, probably makes it more relevant to focus on effects for specific explanatory variables and grassland conditions instead of the overall results.

\subsection{Evaluation of the effect outcome}

The papers included in this thesis used different outcomes to measure the effect of the management methods on the biodiversity of semi-natural grasslands. The outcomes measured were species richness (paper IV and V, among other similar outcomes), occurrence of indicator species (paper II) or both (paper I and III). However, it is somewhat unclear which outcome is most relevant to use when evaluating management effects on the biodiversity of semi-natural grasslands. Ideally, a measure of biodiversity should have both high reliability and validity, i.e. be representative for the investigated populations and accurately measure what it intends to (Golafshani 2003). As aims are often based on developing management recommendations, an effect outcome should be applicable, comparable and representative across different types of species and grassland conditions, have a low amount of subjectivity and be a relevant outcome from a grassland conservation viewpoint.

Generally, the goal of studies focusing on the conservation of semi-natural grasslands has been to maximise the species richness. One reason for this is the fact that it is relatively straightforward to assess the species richness and 
density, thus providing a simple way of comparing management methods. However, because of differing regional species pools and abiotic conditions between grasslands, comparisons of species richness are only possible within specific grasslands or between very similar grasslands. Comparisons of species richness or density across studies may also be misleading, as the sampling effort, e.g. the size and number of survey plots, often differ between studies (Gotelli \& Colwell 2001). The difficulties in comparing species richness across sites and studies are possible to overcome by comparing effect sizes instead, e.g. by comparing the standardised mean difference in species richness between treatments and grasslands (Koricheva et al. 2013). Nevertheless, it is unclear what the species richness actually signifies regarding the conservation value of semi-natural grasslands (for this thesis, a semi-natural grassland of high conservation value is defined as a well-managed grassland with a high diversity of desired grassland species). A high species richness is often assumed to be an indicator of a high conservation value, or at least that it provides an insight into the state of ecological processes, but this is not necessarily the case (Fleishman et al. 2006). For example, the plant species richness says little about the actual structure of the plant community, as a community with high species richness but low evenness is quite different from one with similar richness (and species), but with more evenly distributed species abundances. The identity of species is also important, at least when conservation is the main objective, as a grassland with many common or generalist species is less important to preserve as one with many rare or specialist species. Thus, the outcome in focus should be a species-rich community consisting of desirable grassland species, and not only species richness in itself. Another important factor to consider is the scale at which the species richness is measured. The species richness per $\mathrm{m}^{2}$ is probably more sensitive to changes compared to the species richness of an entire grassland. From a meta-community perspective it is also important to consider the species richness both within a site and in the surrounding landscape (see Box 1). In addition, it is possible that different management methods affect the community structure (e.g. identity and abundance of species) more than the actual species richness. This is especially true in short-term studies, where it is doubtful if management changes have had time to eliminate the occurrence of a species, but may still have decreased its abundance (e.g. Milberg et al. 2014), i.e. the presence of extinction debt (Kuussaari et al. 2009).

Indicator species is an option to using species richness for evaluation of management effects. Indicator species are usually easily monitored organisms that are native, rare or threatened, play an important role in maintaining ecological function and are capable of detecting both short- and long-term ecological changes (Fleishman et al. 2006, Siddig et al. 2016). Using indicator species may be more useful than using species richness to evaluate management effects. This is a consequence of indicator species potentially being more directly connected to the conservation value of semi-natural grassland and that these 
reveal more about the identity of species and the community structure. For example, indicator species can be used to monitor changes in the number of desirable or undesirable species from a conservation viewpoint. It has also been suggested that indicator species may provide a good proxy for species richness (e.g. Gilby et al. 2017). This actually turned out to be the case based on the data from paper II and III, which revealed an increasing species number per $5 \mathrm{~m}^{2}$ with increasing numbers of indicators of good management (Figure 11). However, as for species richness, it is only relevant to compare presence of indicators between different grasslands and studies using effect sizes, e.g. comparing the ratio of indicators and non-indicators of well-managed grasslands. In addition, it is important to only use indicator systems developed for relevant conditions and regions, as the reliability of an indicator system decreases outside of its intended area of use (Jansson et al. 2009). There are some further limitations to using indicator species: A review of how ecologist select and use indicator species by Sidding et al. (2016) state that often the selection criteria for the indicators are subjective; the connection between an indicator, the environmental context and conservation value can be unclear; there can be methodological difficulties in defining and using indicator species; and future environmental and climatic changes might influence how useful a current indicator species or system might be.

One potential substitute to using species richness or indicator species to evaluate management differences is investigating effects on the distribution of plant functional traits and/or the functional diversity. These are measures of the extent of functional differences between species in a community, often

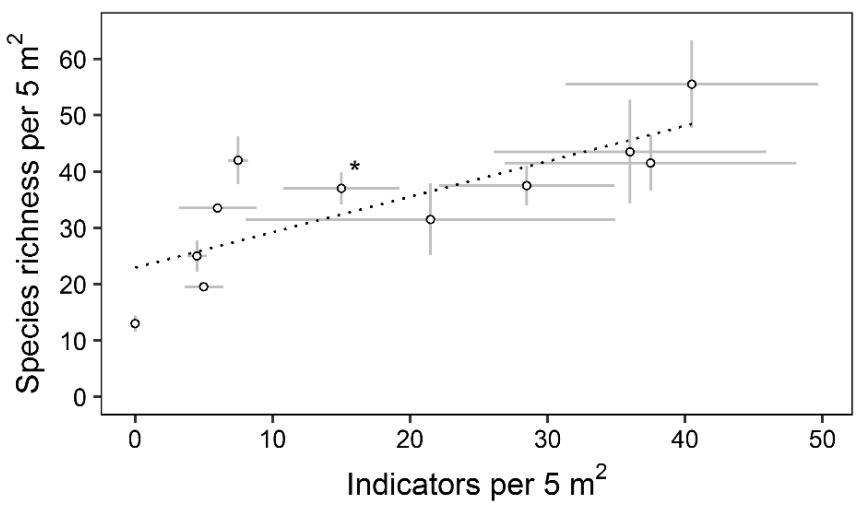

Figure 11 | The relationship between the number of indicators of good management and the species richness per $5 \mathrm{~m}^{2}$ in the experimental sites included in paper II and III. Each point is the mean $( \pm \mathrm{SD})$ of the two blocks in each site. The site marked with an asterisk only used $3 \mathrm{~m}^{2}$. The slope of the linear regression is $0.629\left(F_{1,9}=15.21\right.$, $p=0.004$ ). The indicator system is based on Ekstam and Forshed (1992) (see Table 2). 
represented by the number of functional traits or groups. A high diversity of functional traits or groups is desirable as it ensures the stability of food webs and maintain ecological processes and ecosystem services (Tilman 2001). Studies have found different functional plant traits to be favoured by different types of grassland management and it may therefore be a good way of evaluating management effects (e.g. Kahmen et al. 2002, Louault et al. 2005). However, it is often more time-consuming and difficult to estimate functional diversity, as it requires knowledge on e.g. species traits and/or taxonomy, and might therefore not be a convenient substitute to e.g. species richness (Petchey \& Gaston 2002, Tilman 2001).

Evidently, there are both positive and negative aspects of using species richness, indicator species and functional diversity to evaluate management effects on the biodiversity of semi-natural grasslands. For a reliable and valid assessment of management effects, it is probably most useful to consider both the species richness and effects on indicator species (this approach was used in paper I and III). In addition, the use of different types of outcomes potentially strengthens the possibility of including studies in future meta-analyses, with the best scenario being the use of the same outcomes across all studies. However, it might be somewhat unclear which conclusions to draw if effects differ for different outcomes. This was the case in paper III, where annual mowing had a more positive effect on species richness while the mowing frequencies had similar effects for the indicators. In such cases, the size of the effect and the management aims must be considered when drawing conclusions. For example, if the aim is purely conservation, with no direct consideration of e.g. ecosystem services, it is probably most relevant to focus on effects on indicator species.

\subsection{Management implications}

One of the aims of this thesis was to provide management recommendations for semi-natural grasslands based on the results from the included papers, as a part of the growing field of evidence-based conservation. This type of conservation involves the assembly of information from many different sources with the aim of finding the best available evidence in support of e.g. the use of a particular management method in semi-natural grasslands. This evidence can then be used to support managers and policy makers in choosing a suitable management practice (Pullin \& Knight 2004, Sutherland et al. 2004). Overall, the results from the papers included in this thesis have increased the evidence-base regarding management effects, and they can be used by researchers, managers and policymakers to make more informed management choices.

The results from paper I suggest a greater management flexibility, as mowing using a grass trimmer and sickle bar mower had similar effects, and thus can both be recommended for use in semi-natural grasslands. For large areas with level surface the use of sickle bar mowers is probably more time-efficient, while 
grass trimmers may be a more suitable alternative in small grasslands or grasslands with steep slopes or stony ground (Priha 2003, Stenholm Jakobsen 2015). However, the cultural value of traditional mowing using scythes is a possible consideration when deciding on a mowing technique. In addition, while not studied in paper I, effects on other organisms than plants are another important consideration. Negative effects of mechanical mowing techniques, in particular rotary mowers compared to bar mowers (e.g. sickle bar mowers), have been found on both vertebrate (e.g. amphibians, turtles) and invertebrate species (e.g. butterflies, grasshoppers), usually due to direct mortality during mowing (Humbert et al. 2009, 2010). Therefore, the specific conservation aim (e.g. plants vs. insects) must be considered when picking mowing techniques. It is important to note that these recommendations are based on an experiment performed in one Swedish semi-natural grassland. Therefore, confirmatory studies performed in more grasslands across Europe, involving additional mowing techniques and organisms are needed for more general conclusions to be possible.

According to results from paper II, mowing had the most positive effect on plants in semi-natural grasslands in southern Sweden. However, as differences were small between grazing and mowing, both methods can be recommended in semi-natural grasslands. This was also the case in paper III, where annual mowing and mowing every third year had relatively similar effects and can be recommended for use. This also suggest a greater management flexibility, as the management can be chosen based e.g. on costs, availability of livestock and conservation aims.

When considering grassland in general, and not only those in southern Sweden, the overall effect of grazing and mowing was similar in paper IV, with grazing having a slightly more positive effect on the biodiversity. Nevertheless, it is probably most relevant to base management recommendations for a specific grassland on the results of comparisons of explanatory variables like e.g. grassland type or previous management. The same is true for paper $\mathrm{V}$, which revealed that perhaps the most important factor is that mowing is performed while the mowing frequency is of less importance, but where effects also differed for different grassland characteristics. From a cost-perspective, grazing is probably less expensive than annual mowing (e.g. based on subsidies to Swedish farmers for management of semi-natural grasslands of high conservation value ${ }^{1}$; Swedish Board of Agriculture 2017). If mowing is used, it is effective enough to perform mowing more seldom than annually, at least in less productive grasslands. For example, mowing every other year could mean that the area of mowed grasslands could be considerably extended. However, effectively

${ }_{1} 2800$ SEK/ha for grazing vs. 4500 SEK/ha for mowing in 2017. 
decreasing the amount of subsidies to private farmers for each grassland might decrease the incentive to keep up management despite the decreased management cost per grassland. Nevertheless, less frequent mowing could still be an alternative in the public or non-profit sector.

Together, the small differences in effects in the papers included in this thesis suggest that to a certain extent, one of the most important factors for seminatural grassland biodiversity is that management occurs at all. The actual management method or intensity used is of less importance. Therefore, the most suitable management method for a certain situation should be based on the previous management practice used, grassland conditions, the cost of management, the availability of different management methods and previous research. In addition, as effects may differ for different organisms or grassland characteristics (as evident in paper IV and V) the conservation aim must also be considered when choosing management method.

\subsection{Further research topics}

The papers included in this thesis and other studies examining management effects on semi-natural grassland biodiversity have contributed to the current understanding of management effects. However, for a more complete picture of management effects and management implications and to facilitate more informed management decision, further research is necessary.

This thesis has focused on effects of grazing and mowing, but there are other management options available. One such option is mulching, where the vegetation is cut in a similar way as for mowing, but where the cut material is crushed and left in the grassland, a method often used as an alternative to abandonment (Doležal et al. 2011, Gaisler et al. 2013). Studies examining effects of mulching have concluded that mulching has a similar effect as grazing or mowing at a similar intensity (Kahmen et al. 2002, Mašková et al. 2009). Another option is burning of semi-natural grassland vegetation during late winter or early spring, before the start of the growing season, to remove excess biomass and woody species (Deák et al. 2014). Previous short-term studies have mainly found positive effects of burning compared to other management methods, with higher plant and insect biodiversity in burned plots (Hermanova, 2011, Larsson \& Persson 2012), while longer-term studies have found mostly negative effects of burning (Köhler et al. 2005, Milberg et al. 2014, 2018, Moog et al. 2002). However, there is a need for further research on effects of mulching and burning in different types of grasslands and organisms. For example, there is a lack of studies examining effects on insects, or the effect of mulching outside of central Europe. In addition, there is a need for meta-analyses examining effects of these management methods, specifically as both burning and mulching may be more cost-effective compared to grazing and mowing. 
There is a lack of studies examining effects of grazing intensity on grassland biodiversity. By examining the effect of e.g. continuous vs. rotational grazing, different grazing intensities, different timing of grazing and effects of grazing in different types of grasslands and for different organisms, it will become easier to select suitable grazing regimes for specific species or grassland conditions. In addition, there is a need for researchers (and managers) to be clearer in the characterisation of the grazing intensity and not rely on characterization based on personal assessments, like e.g. "continuous grazing" or "high grazing intensity". Using e.g. Livestock Units will simplify the evaluation of effects of grazing intensities.

Studies focusing on effects of different mowing techniques on both biodiversity in general and individual plant species are also needed. More techniques need to be included in analyses as well as more grassland types. If the effects of more techniques are known, managers can select techniques based on the needs of individual species and the availability of different mowing machines. It would also be useful to compare effects on a larger scale using meta-analyses. In addition, there is a need for large-scale meta-analysis studies examining effects of different mowing dates (e.g. mowing at the beginning or end of summer), to further improve management recommendations.

There is also a need for studies directly examining the cost and timeconsumption of different management methods for different situations. In addition, there is a need to make the research performed more readily available for the community as a whole, to ensure that the best available evidence is used when management plans are made. As the use of systematic reviews and metaanalyses are important tools when making management recommendations, another important consideration is the quality of future studies. Studies of low quality, or studies lacking vital information on e.g. experimental design might be impossible to include in future meta-analyses. Therefore, it is important for researchers to examine management effects in several study sites, with the same, clearly defined treatments between sites and more than one replicate within each site. The use of consistent nomenclature which clearly defines what represents e.g. a replicate, is also necessary. In addition, it is extremely important to present data in a usable way (e.g. means and variance), and not only p-values, to limit the exclusion of studies. For example, for paper IV, the full text of 525 studies were examined in detail and 190 of these had to be excluded from analyses due to lack of data.

\subsection{Conclusions}

The papers included in this thesis suggest that different management methods have different effects on the biodiversity of semi-natural grasslands, but that in general, these differences were quite small. Thus, one of the most important factors for the conservation of semi-natural grassland biodiversity seems to be 
the fact that management occurs at all, while the actual management method and its intensity are of less importance. Hence, choosing the most suitable management method in a certain situation should be based on conservation aims, grassland conditions, the previous management practice used, the cost of management, the availability of different management methods and previous research. 


\section{REFERENCES}

Adler, P.B., Raff, D.A. \& Lauenroth, W.K. 2001. The effect of grazing on the spatial heterogeneity of vegetation. Oecologia, 128, 465-479.

Al-Mufti, M.M., Sydes, C.L., Furness, S.B., Grime, J.P. \& Band, S.R. 1977. A quantitative analysis of shoot phenology and dominance in herbaceous vegetation. Journal of Ecology, 65, 759-791.

Balvanera, P., Pfisterer, A.B., Buchmann, N., He, J.-S., Nakashizuku, T., Raffaeli, D. \& Schmid, B. 2006. Quantifying the evidence for biodiversity effects on ecosystem functioning and services. Ecology Letters, 9, 1145-1156.

Batáry, J.P., Báldi, A., Sárospataki, M., Kohler, F., Verhulst, J., Knop, E., Herzog, G. \& Kleijn, D. 2010. Effect of conservation management on bees and insectpollinated grassland plant communities in three European countries. Agriculture, Ecosystems and Environment, 136, 35-39.

Bazzoffi, P. 2009. Soil erosion tolerance and water runoff control: minimum environmental standards. Regional Environmental Change, 9, 169-179.

Bellamy, P.E., Shore, R.F., Ardeshir, D., Treweek, J.R. \& Sparks, T.H. 2000. Road verges as habitats for small mammals in Britain. Mammal Review, 30, 137-139.

Beltman, B., van den Broek, T., Martin, W., Ten Cate, M. \& Güsewell, S. 2003. Impact of mowing regime on species richness and biomass of a limestone hay meadow in Ireland. Bulletin of the Geobotanical Institute ETH, 69, 17-30.

Bertilsson, A. \& Paltto, H. 2003. Hagar i Skaraborg: en återinventering med miljöövervakningssyfte. County Administration Board of Västra Götaland, 2003:15.

http://www.lansstyrelsen.se/vastragotaland/SiteCollectionDocuments/Sv/p ublikationer/2003/rapport200315.pdf. Accessed 2017-12-06.

Biostat, Inc. 2006. Comprehensive meta-analysis, ver. 2. www.meta-analysis.com

Biró, M., Czúcz, B., Horváth, F., Révész, A., Csatári, B. \& Molnár, Z. 2013. Drivers of grassland loss in Hungary during the post-socialist transformation (1987-1999). Landscape Ecology, 28, 789-803.

Bonari, G., Fajmon, K., Malenovský, I., Zelený, D., Holuša, J., Jongepierová, I., Kočárek, P., Konvička, O., Uřičář, J., \& Chytrý, M. (2017) Management of semi-natural grasslands benefiting both plant and insect diversity: the importance of heterogeneity and tradition. Agriculture, Ecosystem and Environment, 246, 243-252. 
Borenstein, M., Hedges, L.V., Higgins, J.P.T \& Rothstein, H.R. 2009. Introduction to Meta-Analysis. Chichester: Wiley.

Bradshaw, R. \& Mitchell, F.J.G. 1999. The paleoecological approach to reconstructing former grazing-vegetation interactions. Forest Ecology and Management, 120, 3-12.

Bruppacher, L., Pellet, J., Arlettaz, R. \& Humbert, J.-Y. 2016. Simple modifications of mowing regime promotes butterflies in extensively managed meadows: evidence from field-scale experiments. Biological Conservation, 196, 196-202.

Brys, R., Jacquemyn, H., Endels, P., De Blust, G. \& Hermy, M. 2004. The effects of grassland management on plant performance and demography in the perennial herb Primula veris. Journal of Applied Ecology, 41, 1080-1091.

Bullock, J.M., Jefferson, R.G., Blackstock, T.H., Pakeman, R.J., Emmett, B.A., Pywell, R.J., Grime, J.P. \& Silvertown, J. 2011. Semi-natural grasslands. In: The UK National Ecosystem Assessment Technical Report. UK National Ecosystem Assessment. Cambridge: UNEP-WCMC. pp. 162-195.

Catorci, A., Cesaretti, S., Malatesta, L. \& Tardella, F.M. 2014. Effects of grazing vs mowing on the functional diversity of sub-Mediterranean productive grasslands. Applied Vegetation Science, 17, 658-669.

Chaudron, C., Chauvel, B. \& Isselin-Nondedeu, F. 2016. Effects of late mowing on plant species richness and seed rain in road verges and adjacent arable fields. Agriculture, Ecosystems and Environment, 232, 218-226.

Chesson, P.L 1986. Coexistence of competitors in spatially and temporally varying environments: a look at the combined effects of different sorts of variability. Theoretical Population Biology, 28, 263-287.

Chesterton, C. 2006. Revised calculation of livestock units for higher level stewardship agreements, technical advice note 33. $2^{\text {nd }}$ edition. Rural Development Service.

https://web.archive.org/web/20070626001539/http://www.defra.gov.uk/r ds/publications/technical/tan 33.pdf. Archived 2007-06-26.

Chytrý, M. et al. 2015. The most species-rich plant communities in the Czech Republic and Slovakia (with new world records). Preslia, 87, 217-278.

Cizek, O., Zamecnik, J., Tropek, R., Kocarek, P. \& Konvicka, M. 2012. Diversification of mowing regime increases arthropods diversity in speciespoor cultural hay meadows. Journal of Insect Conservation, 16, 215-226.

Cohen, J. 1992. A power primer. Psychological Bulletin, 112, 155-159.

Crawley, M.J. 1997. Plant Ecology. 2nd edn. Oxford: Blackwell Science Ltd. 
Crofts, A. \& Jefferson, R.G. 1999. The Lowland Grassland Management Handbook. 2nd edn. Peterborough: English Nature/The Wildlife Trusts.

D'Aniello, B., Stanislao, I., Bonelli, S. \& Balletto, E. 2011. Haying and grazing effects on the butterfly communities of two Mediterranean-area grasslands. Biodiversity and Conservation, 20, 1731-1744.

De Mazancourt, C., Loreau, M. \& Abbadie, L. 1998. Grazing optimization and nutrient cycling: when do herbivores enhance plant production? Ecology, 79, 2242-2252.

Deák, B., Valkó, O., Török, P., Végvári, Z.S., Hartel, T. \& Schmotzer, A. 2014. Grassland and fires in Hungary - Experiences of nature conservationists on the effects of fire on biodiversity. Applied Ecology and Environmental Research, 12, 267-283.

Deng, L., Sweeney, S. \& Shangguan, Z.-P. 2014. Grassland responses to grazing disturbance: plant diversity changes with grazing intensity in a desert steppe. Grass and Forage Science, 69, 524-533.

Dicks, L.V. et al. 2017. Farmland conservation. In Sutherland, W.J., Dicks, L.V., Ockendon, N. \& Smith, R.K. (eds.) What works in conservation. Cambridge: Open Book Publishers. Pp. 245-284.

Dobrev, V., Popgeorgiev, G. \& Plachiyski, D. 2014. Effects if the common agricultural policy on the coverage of grassland habitats in Besaparski Ridove species protection area (Natura 2000), Southern Bulgaria. Acta Zoologica Bulgarica, 66, 147-155.

Dolek, M. \& Geyer, A. 2002. Conserving biodiversity on calcareous grasslands in the Franconian Jura by grazing: a comprehensive approach. Biological Conservation, 104, 351-360.

Doležal, J., Mašková, Z., Lepš, J., Steinbachová, D., de Bello, F., Klimešová, J., Tackenberg, O., Zemek, F. \& Květ, J. 2011. Positive long-term effect of mulching on species and functional trait diversity in a nutrient-poor mountain meadow in Central Europe. Agriculture, Ecosystems and Environment, 145, 10-28.

During, H. \& Willems, J.H. 1984. Diversity models applied to a chalk grassland. Vegetatio, 57, 103-114.

Dwan, K., Gamble, C., Williamson, P.R. \& Kirkham, J.J. 2013. Systematic review of the empirical evidence of study publication bias and outcome reporting bias - an updated review. PLoS One, 8:e66844.

Egger, M., Smith, G.D. \& Minder, C. 1997. Bias in meta-analysis detected by a simple, graphical test. $B M J, 315: 629$. 
Einarsson, A. \& Milberg, P. 1999. Species richness and distribution in relation to light in wooded meadows and pastures in southern Sweden. Annales Botanici Fennici, 36. 99-107.

Ekstam, U., Aronsson, M. \& Forshed, N. 1988. Ängar. Stockholm: LTs förlag.

Ekstam, U. \& Forshed, N. 1992. Om hävden upphör: kärlväxter som indikatorarter i ängs- och hagmarker. Stockholm: Naturvårdsverket.

Eriksson, O., Bolmgren, K., Westin, A. \& Lennartsson, T. 2015. Historic haycutting dates from Sweden 1873-1951 and their implication for conservation management of species-rich meadows. Biological conservation, 184, 100107.

Eriksson, O., Cousins, S \& Bruun, H.H. 2002. Land-use history and fragmentation of traditionally managed grasslands in Scandinavia. Journal of Vegetation Science, 13, 743-748.

European Commission Directorate General for Agriculture and Rural Development 2005. Agri-environment Measures. Overview of General Principles, Types of Measures, and Applications. http://ec.europa.eu/agriculture/publi/reports/agrienv/rep en.pdf. Accessed 2017-12-06.

Everwand, G., Rösch, V., Tscharntke, T. \& Scherber, C. 2014. Disentangling direct and indirect effects of experimental grassland management and plant functional-group manipulation on plant and leafhopper diversity. $B M C$ Ecology, 14:1.

Fahrig, L. 2003. Effects of habitat fragmentation on biodiversity. Annual Review of Ecology, Evolution and Systematics, 34, 487-515.

Fay, P.A., Kaufman, D.M., Nippert, J.B., Carlisle, J.D. \& Harper, C.W. 2008. Changes in grassland ecosystem function due to extreme rainfall events: implications for responses to climate change. Global Change Biology, 4, 1600-1608.

Firbank, L.G. 2005. Striking a new balance between agricultural production and biodiversity. Annals of Applied Biology, 146, 163-175.

Fischer, M. \& Wipf, S. 2002. Effect of low-intensity grazing on the species-rich vegetation of traditionally mown subalpine meadows. Biological Conservation, 104, 1-11.

Fleishman, E., Noss, R.F. \& Noon, B.R. 2006. Utility and limitations of species richness metrics for conservation planning. Ecological Indicators, 6, 543553 . 
Gaisler, J., Pavlů, V., Pavlů, L., Hejcman, M. 2013. Long-term effects of different mulching and cutting regimes on plant species composition of Festuca rubra grassland. Agriculture, Ecosystems \& Environment, 178, $10-17$.

Garibaldi, L.A. et al. 2011. Stability of pollination services decreases with isolation from natural areas despite honey bee visits. Ecology Letters, 14, 1062-1072.

Gibson, D.J. 2009. Grasses and Grassland Ecology. Oxford: Oxford University Press.

Gilby, B.L., Olds, A.D., Connolly, R.M., Yabsley, N.A., Maxwell, P.S., Tibbetts, I.R., Schoeman, D.S. \& Schlacher, T.A. 2017. Umbrellas can work under water: using threatened species as indicator and management surrogates can improve coastal conservation. Estuarine, Coastal and Shelf Science, 199, 132140.

Gilhaus, K., Boch, S., Fischer, M., Hölzel, N., Kleinebecker, T., Prati, D., Rupprecht, D., Schmitt, B. \& Klaus, V.H. 2017. Grassland management in Germany: effects on plant diversity and vegetation composition. Tuexenia, 37, 379-397.

Gilhaus, K. \& Hölzel, N. 2016. Seasonal variations of fodder quality and availability as constraints for stocking rates in year-round grazing schemes. Agriculture, Ecosystems and Environment, 234, 5-15.

Glass, G.V. 1976. Primary, secondary, and meta-analysis of research. Educational Researcher, 5, 3-8.

Golafshani, N. 2003. Understanding reliability and validity in qualitative research. The Qualitative Report, 8, 597-607.

Golodets, C., Kigel, J. \& Sternberg, M. 2010. Recovery of plant species composition and ecosystem function after cessation of grazing in a Mediterranean grassland. Plant and Soil, 329, 365-378.

Gosteli, M. 1996. Diversities of snail faunas and ecological relationships between snail communities and vegetation in dry habitats of the northern Swiss Jura (Gastropoda: Prosobranchia et Pulmonata). Malakologische Abhandlungen, $181,107-123$

Gotelli, N.J. \& Colwell, R.K. 2001. Quantifying biodiversity: procedures and pitfalls in the measurement and comparison of species richness. Ecology Letters, 4, 379-391.

Gonzalez, A., Cardinale, B.J., Allington, G.R.H., Byrnes, J., Endsley, A., Brown, D.G., Hooper, D.U., Isbell, F., O’Connor, M.I. \& Loreau, M. 2016. Estimating local biodiversity change: a critique of papers claiming no net loss of local diversity. Ecology, 97, 1949-1960. 
Grubb, P.J. 1977. The maintenance of species-richness in plant communities: the importance of the regeneration niche. Biological Reviews, 52, 107-145.

Haddad, N.M., Crutsinger, G.M., Gross, K., Haarstad, J. \& Tilman, D. 2011. Plant diversity and the stability of foodwebs. Ecology Letters, 14, 42-46.

Hansson, M. 1991. Management of semi-natural grassland. Results of a fifteenyear-old field experiment in south and central Sweden. Report no. 45. Uppsala: Department of Ecology and Environmental Research, Swedish University of Agricultural Sciences.

Hansson, M. \& Fogelfors, H. 2000. Management of semi-natural grassland; results from a 15-year old experiment in southern Sweden. Journal of Vegetation Science, 11, 31-38.

Hejcman, M., Hejcmanová, P., Pavlů, V. \& Beneš, J. 2013. Origin and history of grasslands in Central Europe - a review. Grass and Forage Science, 68, 345363.

Hermanova, M. 2011. Vliv obhospodařování na druhovou skladbu a funkční charakteristiky travních porosti̊. Thesis, Univerzita Palackého v Olomouci. http://theses.cz/id/zp1avi/o0082760-659514486.pdf. Accessed 2017-09-14.

Holechek, J.L. 1988. An approach for setting the stocking rate. Rangelands, 1, 10-14.

Holyoak, M., Leibold, M.A., Mouquet, N.M., Holt, R.D. \& Hoopes, M.F. 2005. Metacommunities: a framework for large-scale community ecology. In Holyoak, M., Leibold, M.A. \& Holt, R.D. (eds.) Metacommunities: spatial dynamics and ecological communities. Chicago: The University of Chicago Press.

Hönigová, I., Vačkář, D., Lorencová, E., Melichar, J., Götzl, M., Sonderegger, G., Oušková, V., Hošek, M. \& Chobot, K. 2012. Survey on grassland ecosystem services. Report of the European Topic Centre on Biological Diversity. Prague: Nature Conservation Agency of the Czech Republic, pp. 78.

Hooper, D.U. et al. 2005. Effects of biodiversity on ecosystem functioning: a consensus of current knowledge. Ecological Monographs, 75, 3-35.

Humbert, J.-Y., Dwyer, J.M., Andrey, A. \& Arlettaz, R. 2016. Impacts of nitrogen addition on plant biodiversity in mountain grasslands depend on dose, application duration and climate: a systematic review. Global Change Biology, 22, 110-120.

Humbert, J.-Y., Ghazoul, J., Sauter, G.J. \& Walter, T. 2010. Impact of different meadow mowing techniques on field invertebrates. Journal of Applied Entomology 
Humbert, J.-Y., Ghazoul, J. \& Walter, T. 2009. Meadow harvesting techniques and their impacts on field fauna. Agriculture, Ecosystems and Environment, 130, $1-8$.

Humbert, J.-Y., Pellet, J., Buri, P. \& Arlettaz, R. 2012. Does delaying the first mowing date benefit biodiversity in meadowland? Environmental Evidence, 1:9.

Ihse, M. 1995. Swedish agricultural landscape - patterns and changes during the last 50 years, studied by aerial photos. Landscape and Urban Planning, $3,21-37$.

Jansson, N., Bergman, K.-O., Jonsell, M. \& Milberg, P. 2009. An indicator system for identification of sites of high conservation value for saproxylic oak (Quercus spp.) beetles in southern Sweden. Journal of Insect Conservation, 13, 399-412.

Jacobo, E.J., Rodríguez, A.M., Bartoloni, N. \& Deregibus, V.A. 2006. Rotational grazing effects on rangeland vegetation at a farm scale. Rangeland Ecology \& Management, 59, 249-257.

Jantunen, J., Saarinen, K., Valtonen, A. \& Saarnio, S. 2007. Flowering and seed production success along roads with different mowing regimes. Applied Vegetation Science, 10, 285-292.

Kahmen, S. \& Poschlod, P. 2008. Does germination success differ with respect to seed mass and germination season? Experimental testing of plant functional trait responses to grassland management. Annals of Botany, 101, 541-548.

Kahmen, S., Poschlod, P. \& Schreiber, K.-F. 2002. Conservation management of calcareous grasslands. Changes in plant species composition and response of functional traits during 25 years. Biological Conservation, 104, 319-328.

Karlík, P. \& Poschlod, P. 2014. Soil seed bank composition reveals the land-use history of calcareous grasslands. Acta Oecologica, 58, 22-34.

Kelemen, A., Török, P., Valkó, O., Deák, B., Miglécz, T., Tóth, K., Ölvedi, T., \& Tóthmérész, B. 2014. Sustaining recovered grasslands is not likely without proper management: vegetation changes after cessation of mowing. Biodiversity and Conservation, 23, 741-751.

Kelemen, A., Török, P., Valkó, O., Miglécz, T. \& Tóthmérész, B. 2013. Mechanisms shaping plant biomass and species richness: plant strategies and litter effect in alkali and loess grasslands. Journal of Vegetation Science, 24, 1195-1203.

Kiær, L.P., Weisbach, A.N. \& Weiner, J. 2013. Root and shoot competition: a meta-analysis. Journal of Ecology, 101, 1298-1312. 
Klimek, S., Richter gen. Kemmermann, A., Hofmann, M. \& Isselstein, J. 2007. Plant species richness and composition in managed grasslands: the relative importance of field management and environmental factors. Biological Conservation, 134, 559-570.

Knop, E., Kleijn, D., Herzog, F. \& Schmid, B. 2006. Effectiveness of the Swiss agri-environmental scheme in promoting biodiversity. Journal of Applied Ecology, 43, 120-127.

Köhler, B., Gigon, A., Edwards, P.J., Krüsi, B., Lagenauer, R., Lüscher, A. \& Ryser, P. 2005. Changes in the species composition and conservation value of limestone grasslands in Northern Switzerland after 22 years of contrasting managements. Perspectives in Plant Ecology, Evolution and Systematics, 7, 51-67.

Koncz, P., Besnyői, V., Csathó, A.I., Nady, J., Szerdahelyi, T., Tóth, Z.S., Pintér, K., Balogh, J., Nagy, Z. \& Bartha, S. 2014. Effect of grazing and mowing on the microcoenological composition of a semi-arid grassland in Hungary. Applied Ecology and Environmental Research, 12, 563-575.

Koricheva, J. \& Gurevitch, J. 2014. Uses and misuses of meta-analysis in plant ecology. Journal of Ecology, 102, 828-844.

Koricheva, J., Gurevitch, J. \& Mengersen, K. 2013. Handbook of meta-analysis in ecology and evolution, Princeton: Princeton University Press.

Kőrösi, Á., Szentirmai, I., Batáry, P., Kövér, S. \& Örvössy, N. 2014. Effects of timing and frequency of mowing on the threatened scarce large blue butterfly - A fine-scale experiment. Agriculture, Ecosystems and Environment, 196, 24-33.

Kull, K. \& Zobel, M. 1991. High species richness in an Estonian wooded meadow. Journal of Vegetation Science, 2, 711-714.

Kumm, K.-I. 2003. Sustainable management of Swedish seminatural pastures with high species diversity. Journal for Nature Conservation, 11, 117-125.

Kuussaari, M. et al. 2009. Extinction debt: a challenge for biodiversity conservation. Trends in Ecology \& Evolution, 24, 564-571.

Lagendijk, D.D.G., Howinson, R.A., Esselink, P., Ubels, R. \& Smit, C. 2017. Rotation grazing as a conservation management tool: vegetation changes after six years of application in a salt marsh ecosystem. Agriculture, Ecosystems and Environment, 246, 361-366.

Lajeunesse, M.J. 2015. Bias and correction for the log response ratio in ecological meta-analysis. Ecology, 96, 2056-2063. 
Lamarque, P., Tappeiner, U., Turner, C., Steinbacher, M. \& Bardgett, R.D. 2011. Stakeholder perceptions of grassland ecosystem services in relation to knowledge on soil fertility and biodiversity. Regional Environmental Change, 11, 791-804.

Lamb, E.G., Kembel, S.W. \& Cahill, J.F. 2009. Shoot, but not root, competition reduces community diversity in experimental mesocosms. Journal of Ecology, 97, 155-163.

Larsson, B.M.P. \& Ekstam, U. 1987. Inventering av ängs- och hagmarker: indikatorarter för hävdad och ogödslad mark. Stockholm: Naturvårdsverket.

Larsson, K., Persson, K. 2012. Naturvårdsbränning i gräsmarker: en jämförande studie av bete, bränning och slåtter 2010-2012. Jordbruksverket, Jönköping. http://www.jordbruksverket.se/download/18.1fec19c313cf285924f8000426 9/Naturv\% 3 \%A5rdsbr\%C3\%A4nning+slutrapport+2010-2012.pdf. Accessed 2017-09-14.

Leibold, M.A. 1995. The niche concept revisited: mechanistic models and community context. Ecology, 76, 1371-1382.

Lepš, J. 1995. Use of paired plots and multivariate analysis for the determination of goat grazing preference. Journal of Vegetation Science, 6, 37-42.

Lepš, J. 2014. Scale- and time-dependent effects of fertilization, mowing and dominant removal on a grassland community during a 15-year experiment. Journal of Applied Ecology, 51, 978-987.

Littlewood, N.A., Stewart, A.J.A. \& Woodcock, B.A. 2012. Science into practice: how can fundamental science contribute to better management of grasslands for invertebrates? Insect Conservation \& Diversity, 5, 1-8.

Louault, F., Pillar, V.D., Aufrère, J., Garnier, E. \& Soussana, J.-F. 2005. Plant traits and functional types in response to reduced disturbance in a seminatural grassland. Journal of Vegetation Science, 16, 151-160.

Loydi, A., Eckstein, R.L., Otte, A. \& Donath, T.W. 2013. Effects of litter seedling establishment in natural and semi-natural grasslands: a meta-analysis. Journal of Ecology, 101, 454-464.

Marriott, C.A., Fothergill, M., Jeangros, B., Scottom, M. \& Louault, F. 2004. Long-term impacts of extensification of grassland management on biodiversity and productivity in upland areas. A review. Agronomie, 24, 447462. 
Mašková, Z., Doležal, J., Květ, J., Zemek, F. 2009. Long-term functioning of a species-rich mountain meadow under different management regimes. Agriculture, Ecosystems \& Environment, 132, 192-202.

Milberg, P. 1995. Soil seed bank after eighteen years of succession from grassland to forest. Oikos, 72, 3-13.

Milberg, P. 2014. Evidence-based vegetation management: prospects and challenges. Applied Vegetation Science, 17, 604-608.

Milberg, P., Akoto, B., Bergman, K.-O., Fogelfors, H., Paltto, H. \& Tälle, M. 2014. Is spring burning a viable management tool in semi-natural grasslands? Applied Vegetation Science, 17, 429-441.

Milberg, P., Bergman, K.-O., Cronwall, E., Eriksson, T.I., Glimskär, A., Islamovic, A., Jonason, D., Löfqvist, Z \& Westerberg, L. 2016. Flower abundance and vegetation height as predictors for nectar-feeding insect occurrence in Swedish semi-natural grasslands. Agriculture, Ecosystems and Environment, 230, 47-54.

Milberg, P., Fogelfors, H., Westerberg, L. \& Tälle, M. 2018. Annual burning of semi-natural grasslands for conservation: winners and losers among plant species. Nordic Journal of Botany, in press.

Moog, D., Kahmen, S., Poschlod, P. \& Schreiber, K.-F. 2002. Comparison of species composition between different grassland managements - 25 years fallow experiment of Baden-Württemberg. Applied Vegetation Science, 5, 99106.

Moretto, A.S. \& Distel, R.A. 1999. Effects of selective defoliation on the competitive interaction between palatable and unpalatable grasses native to a temperate semi-arid grassland of Argentina. Journal of Arid Environments, 42, 167-175.

Naturvårdsverket 2011. Natura 20oo: gräsmarker. Vägledning för gräsmarker, beslutade november 2011.

https://www.naturvardsverket.se/Stod-imiljoarbetet/Vagledningar/Skyddad-natur/Natura-2000/Natura-2000Grasmarker. Accessed 2017-12-06.

Newton, A.C., Stewart, G.B, Myers, G., Diaz, A., Lake, S., Bullock, J.M. \& Pullin, A.S. 2009. Impacts of grazing on lowland heathland in north-west Europe. Biological Conservation, 142, 935-947.

Noordjik, J., Delille, K., Schaffers, A.P. \& Sýkora, K.V. 2009. Optimizing grassland management for flower-visiting insects in roadside verges. Biological Conservation, 142, 2097-2103. 
Oates, M.R. 1995. Butterfly conservation within the management of grassland habitats. In Pullin, A.S. (ed.) Ecology and conservation of butterflies. London: Chapman and Hall. pp. 98-112.

Öckinger, E. \& Smith, H.G. 2007. Semi-natural grasslands as population sources for pollinating insects in agricultural landscapes. Journal of Applied Ecology, 44, 50-59.

Oelmann, Y., Broll, G., Hölzel, N., Kleinebecker, T., Vogel, A. \& Schwartze, P. 2009. Nutrient impoverishment and limitation of productivity after 20 years of conservation management in wet grasslands of north-western Germany. Biological Conservation, 142, 2941-2948.

Olff, H. \& Ritchie, M.E. 1998. Effects of herbivores on grassland plant diversity. Trends in Ecology and Evolution, 13, 261-265.

O'Rourke, K. 2007. An historical perspective on meta-analysis: dealing quantitatively with varying study results. Journal of the Royal Society of Medicine, 100, 579-582.

Park, T., Ganguly, S., Tømmervik, H. Euskirchen, E., Høgda, K.-A., Karlsen, S.R., Brovkin, V., Nemani, R.R. \& Myneni, R.B. 2016. Changes in growing season duration and productivity of northern vegetation inferred from longterm remote sensing data. Environmental Research Letters, 11, 084001.

Pärt, T. \& Söderström, B. 1999. The effects of management regimes and location in landscape on the conservation of farmland birds breeding in semi-natural pastures. Biological Conservation, 90, 113-123.

Pärtel, M., Bruun, H.H. \& Sammul, M. 2005. Biodiversity in temperate European grasslands: origin and conservation. In: Lillak, R., Viiralt, R., Linke, A. \& Geherman,V. (Eds.), Integrating Efficient Grassland Farming and Biodiversity. Grassland Science in Europe 10. Tartu: Estonian Grassland Society, pp. 1-14.

Pedersen, E.A. \& Widgren, M. 2011. Agriculture in Sweden 800 BC-AD 1000. In: Myrdal, J., Morell, M. (Eds.), The Agrarian History of Sweden from 4000 $B C$ to $A D$ 200o. Lund: Nordic Academic Press, pp. 46-71.

Petchey, O.L. \& Gaston, K.J. 2002. Functional diversity (FD), species richness and community composition. Ecology Letters, 5, 402-411.

Philibert, A., Loyce, C. \& Makowski, D. 2012. Assessment of the quality of metaanalysis in agronomy. Agriculture, Ecosystems and Environment, 148, 7282.

Poschlod, P. 2015. Geschichte der Kulturlandschaft. Stuttgart: Ulmer. 
Poschlod, P., Hoffmann, J. \& Bernhardt-Römermann, M. 2011. Effects of grassland management on the age and reproduction structure of Helianthemum nummularium and Lotus corniculatus populations. Preslia, 83, 421-435.

Poschlod, P. \& Wallis De Vries, M.F. 2002. The historical and socioeconomic perspective of calcareous grasslands - lessons from the distant and recent past. Biological Conservation, 104, 361-376.

Potts, D.G., Vulliamy, B., Dafni, A., Ne'eman, G. \& Willmer, P. 2003. Linking bees and flowers: how do floral communities structure pollinator communities? Ecology, 84, 2628-2642.

Priha, M. (ed.) 2003. Skötselkort for vårdbiotoper - Häfte 4 Skötselmetoder och skötselkostnader. Finnish Ministry of Agriculture and Forestry. http://www.mavi.fi/sv/guider-ochanvisningar/odlare/Documents/Milj\%C3\%B6st\%C3\%B6dets\%2or\%C3\%A5 dgivande\%20guider/SV Sk\%C3\%B6tselmetoder\%200ch\%20sk\%C3\%B6tsel kostnader.pdf. Accessed 2017-12-08.

Pullin, A.S. \& Knight, T.M. 2004. Support for decision making in conservation practice: an evidence-based approach. Journal for Nature Conservation, 11, 83-90.

Pullin, A.S., Knight, T.M., Stone, D.A. \& Charman, K. 2004. Do conservation managers use scientific evidence to support their decision-making? Biological Conservation, 119, 245-252.

Pullin, A.S. \& Stewart, G.B. 2006. Guidelines for systematic reviews in conservation and environmental management. Conservation Biology, 20, 1647-1656.

Pykälä, J. 2003. Effects of restoration with cattle grazing on plant species composition and richness of semi-natural grasslands. Biodiversity and Conservation, 12, 2211-2226.

Radlmair, S., Laußmann, H. 1997. Auswirkungen extensiver Beweidung und Mahd von Moorstandorten in Süddeutschland auf die Heuschreckenfauna (Saltoria). Verhandlungen des Gesellschaft für Ökologie, 27, 199-205.

Ridding, L.E., Redhead, J.W. \& Pywell, R.F. 2015. Fate of semi-natural grassland in England between 1960 and 2013: a test of national conservation policy. Global Ecology and Conservation, 4, 516-525.

Rook, A.J., Dumont, B., Isselstein, J., Ororo, K., Wallis De Vries, M.F., Parente, G. \& Mills, J. 2004. Matching type of livestock to desired biodiversity outcomes in pastures - a review. Biological Conservation, 119, 137-150. 
Ruprecht, E., Enyedi, M.Z., Eckstein, R.L. \& Donath, T.W. 2010. Restorative removal of plant litter and vegetation 40 years after abandonment enhances re-emergence of steppe grassland vegetation. Biological Conservation, 143, 449-456.

Ryser, P., Langenauer, R. \& Gigon, A. 1995. Species richness and vegetation structure in a limestone grassland after 15 years management with six biomass removal regimes. Folia Geobotanica, 30, 157-167.

Saarinen, K. \& Jantunen, J. 2005. Grassland butterfly fauna under traditional animal husbandry: contrasts in diversity in mown meadows and grazed pastures. Biodiversity and Conservation, 14, 3201-3213.

Sandberg, H. \& Thylén, A. 1999. Maskiner och redskap i naturliga fodermarker. Biologisk mångfald och variation $i$ odlingslandskapet. Jönköping: Jordbruksverket.

Schreiber, K.-F., Brauckmann, H.-J., Broll, G., Krebs, S. \& Poschlod, P. (eds.) 2009. Artenreiches Grünland in der Kulturlandschaft. 35 Jahre Offenhaltungsversuche Baden-Württemberg. Heidelberg: Verlag Regionalkultur.

Schläpfer, M., Zoller, H. \& Körner, C. 1998. Influences of mowing and grazing on plant species composition in calcareous grassland. Botanica Helvetica, $108,57-67$.

Siddig, A.A.H., Ellison, A.M., Ochs, A., Villar-Leeman, C. \& Lau, K. 2016. How do ecologists select and use indicator species to monitor ecological change? Insight from 14 years of publication in Ecological Indicators. Ecological Indicators, 60, 223-230.

Simões, M.P., Belo, A.F. \& Souza, C. 2013. Effect of mowing regime on diversity of Mediterranean roadside vegetation - implications for management. Polish Journal of Ecology, 61, 241-255.

Sjödin, N.E. 2007. Pollinator behavioural responses to grazing intensity. Biodiversity and Conservation, 16, 2103-2121.

Stenholm Jakobsen, R. 2015. Liehandboken. Göteborg: Hantverkslaboratoriet, Göteborgs Universitet.

Stewart, G.B \& Pullin, A.S. 2008. The relative importance of grazing stock type and grazing intensity for conservation of mesotrophic 'old meadow' pasture. Journal of Nature Conservation, 16, 175-185.

Sutherland, W.J., Pullin, A.S., Dolman, P.M. \& Knight, T.M. 2004. The need for evidence-based conservation. Trends in Ecology \& Evolution, 19, 305-308. 
Svensson, R., Pihlgren, A. \& Wissmann, J. 2009. Gräsröjaren - bättre än sitt rykte! Svensk Botanisk Tidskrift, 103, 187-195.

Swedish Board of Agriculture 2017. Ersättningsnivåer för miljöersättningar och ersättningar för ekologisk produktion 2014-202O. http://www.jordbruksverket.se/amnesomraden/stod/jordbrukarstod/miljo ersattningar/ersattningsnivaer.4.613fbaa714beddof2d319ee8.html. Accessed 2017-12-20.

Szépligeti, M., Kőrösi, A., Szentirmai, I., Házi, J., Bartha, D. \& Bartha, S. (2018) Evaluating alternative mowing regimes for conservation management of Central European mesic meadows: a field experiment. Plant Biosystems - An International Journal Dealing with all Aspects of Plant Biology, 152, 90-97.

ter Braak, C.J.F. \& Šmilauer, P. 2012. Canoco reference manual and user's guide: software ordination, version 5.o. Ithaca: Microcomputer power.

Tilman, D. 2001. Functional diversity. In Levin, S.A. (ed.) Encyclopedia of Biodiversity. San Diego: Academic Press, pp. 109-120

Tilman, D., May, R.M., Lehman, C.L. \& Nowak, M.A. 1994. Habitat destruction and the extinction debt. Nature, 371, 65-66.

Török, P., Valkó, O., Deák, B., Kelemen, A., Tóth, E. \& Tóthmérész, B. 2016. Managing for species composition or diversity? Pastoral and free grazing systems in alkali steppes. Agriculture, Ecosystems and Environment, 234, 2330.

Török, P., Vida, E., Deák, M., Lengyel, S. \& Tóthmérész, B. 2011. Grassland restoration on former croplands in Europe: An assessment of applicability of techniques and costs. Biodiversity \& Conservation, 20, 2311-2332.

Tóth, E., Deák, B., Valkó, O., Kelemen, A., Miglécz, T., Tóthmérész, B. \& Török, P. 2016. Livestock type is more crucial than grazing intensity: traditional cattle and sheep grazing in short-grass steppes. Land Degradation and Development, DOI: 10.1002/ldr.2514.

Valtonen, A., Saarinen, K. \& Jantunen, J. 2006. Effect of different mowing regimes on butterflies and diurnal moths on road verges. Animal Biodiversity and Conservation, 29, 133-148.

van Noordwijk, C.G.E., Flierman, D.E., Remke, E., Wallis De Vries, M.F. \& Berg, M.P. 2012. Impact of grazing management on hibernating caterpillars of the butterfly Melitaea cinxia in calcareous grasslands. Journal of Insect Conservation, 16, 909-920.

Verrier, F.J. \& Kirkpatrick, J.B. 2005. Frequent mowing is better than grazing for the conservation value of lowland tussock at Pontville, Tasmania. Austral Ecology, 30, 74-78. 
Vickery, J.A., Tallowing, J.R., Feber, R.E., Asteraki, E.J., Atkinson, P.W., Fuller R.J. \& Brown, V.K. 2001. The management of lowland neutral grasslands in Britain: effects of agricultural practices on birds and their food resources. Journal of Applied Ecology, 38, 647-664.

Wahlman, H. \& Milberg, P. 2002. Management of semi-natural grassland vegetation: evaluation of a long-term experiment in southern Sweden. Annales Botanici Fennici, 39, 159-166.

Wallis De Vries, M.F., Parkinson, A.E., Dulphy, J.P., Sayer, M. \& Diana, E. 2007. Effects of livestock breed and grazing intensity on biodiversity and production in grazing systems. 4. Effects on animal diversity. Grass and Forage Science, 62, $185-197$.

Wallis De Vries, M.F., Poschlod, P. \& Willems, J.H. 2002. Challenges for the conservation of calcareous grasslands in northwestern Europe: integrating the requirements of flora and fauna. Biological Conservation, 104, 265-273.

van Klink, R., van der Plas, F., van Noordwijk, C.G.E., Wallis De Vries, M.F. \& Olff, H. 2015. Effects of large herbivores on grassland arthropod diversity. Biological Reviews, 90, 347-366.

Wilson, J.B., Peet, R.K., Dengler, J. \& Pärtel, M. 2012. Plant species richness: the world records. Journal of Vegetation Science, 23, 796-802.

Yang, D., Han, G., Hu, Y. \& Wuyungerle 2006. Effects of grazing intensity on plant diversity and aboveground biomass of Stipa baicolensis grassland. Chinese Journal of Ecology, 25, 1470-1475.

Zhou, G., Wang, Y. \& Wang, S. 2002. Response of grassland ecosystems to precipitation and land use along the Northeast China transect. Journal of Vegetation Science, 13, 361-368. 


\section{Papers}

The papers associated with this thesis have been removed for copyright reasons. For more details about these see:

http://urn.kb.se/resolve?urn=urn:nbn:se:liu:diva-144796 